Review

\title{
Supply Chain Operations Management in Pandemics: A State-of-the-Art Review Inspired by COVID-19
}

\author{
Muhammad Umar Farooq ${ }^{1,2, * \mathbb{D}}$, Amjad Hussain ${ }^{1, *}$, Tariq Masood ${ }^{3,4} \mathbb{D}$ and Muhammad Salman Habib ${ }^{1}$ (D) \\ 1 Department of Industrial and Manufacturing Engineering, University of Engineering and Technology, \\ Lahore 54890, Pakistan; salmanhabib@uet.edu.pk \\ 2 Department of Industrial and Systems Engineering, Korea Advanced Institute of Science and Technology, \\ Daejeon 34141, Korea \\ 3 Department of Engineering, University of Cambridge, Cambridge CB2 1PZ, UK; tariq.masood@strath.ac.uk \\ 4 Department of Design, Manufacturing and Engineering Management, University of Strathclyde, \\ 75 Montrose Street, Glasgow G1 1XJ, UK \\ * Correspondence: Umarmuf0@gmail.com (M.U.F.); chamjad@uet.edu.pk (A.H.); \\ Tel.: +92-304-887-3688 (M.U.F.)
}

Citation: Farooq, M.U.; Hussain, A.; Masood, T.; Habib, M.S. Supply Chain Operations Management in Pandemics: A State-of-the-Art Review Inspired by COVID-19. Sustainability 2021, 13, 2504. https:// doi.org/10.3390/su13052504

Academic Editor: Alessio Ishizaka

Received: 7 January 2021

Accepted: 19 February 2021

Published: 25 February 2021

Publisher's Note: MDPI stays neutral with regard to jurisdictional claims in published maps and institutional affiliations.

Copyright: (c) 2021 by the authors. Licensee MDPI, Basel, Switzerland. This article is an open access article distributed under the terms and conditions of the Creative Commons Attribution (CC BY) license (https:/ / creativecommons.org/licenses/by/ $4.0 /)$.

\begin{abstract}
Pandemics cause chaotic situations in supply chains (SC) around the globe, which can lead towards survivability challenges. The ongoing COVID-19 pandemic is an unprecedented humanitarian crisis that has severely affected global business dynamics. Similar vulnerabilities have been caused by other outbreaks in the past. In these terms, prevention strategies against propagating disruptions require vigilant goal conceptualization and roadmaps. In this respect, there is a need to explore supply chain operation management strategies to overcome the challenges that emerge due to COVID-19-like situations. Therefore, this review is aimed at exploring such challenges and developing strategies for sustainability, and viability perspectives for SCs, through a structured literature review (SLR) approach. Moreover, this study investigated the impacts of previous epidemic outbreaks on SCs, to identify the research objectives, methodological approaches, and implications for SCs. The study also explored the impacts of epidemic outbreaks on the business environment, in terms of effective resource allocation, supply and demand disruptions, and transportation network optimization, through operations management techniques. Furthermore, this article structured a framework that emphasizes the integration of Industry 4.0 technologies, resilience strategies, and sustainability to overcome SC challenges during pandemics. Finally, future research avenues were identified by including a research agenda for experts and practitioners to develop new pathways to get out of the crisis.
\end{abstract}

Keywords: supply chain management; survivability; epidemic outbreaks; influenza; COVID-19; sustainability; viability; resilience; industry 4.0; review; manufacturing

\section{Introduction}

Disruptions to business operations and global supply chains (SC) caused by disasters have led the practitioners and researchers to focus on survivability, which is the most concerning topic these days [1]. There have been several threats, such as climate changes leading to natural disasters, man-made circumstances (in terms of terrorism), and several other potential risks. Consequently, companies look for ways to survive in tough times and sustain their positions after such events. A potential roadmap for ensuring both objectives is to transform their operations and SC activities into transparent, agile, and reliable cyber-physical systems. Many industrial tycoons have started the journey towards digitalization [2].

Moreover, to survive during disasters, the focus on improving market-share, ecological consciousness, and differentiation through technology leadership, along with a reliable and sustainable SC network requires a workable framework. However, approaches such 
as being lean, green, and resilient, and ensuring sustainability are established, and practiced supporting emerging market requirements. In terms of sustainability, if an SC gets disturbed because of a disaster, the parallel node to the affected location is identified and connected to minimize the disruptions in supplies and demands [3]. Among different types of disasters categorized by the World Health Organization (WHO), epidemic outbreaks have proven to be destructive to human lives as well as economies. The manufacturing setups, which are considered the backbone of any country's economy, often face full or partial closure in such circumstances. The economic effects surpass territorial boundaries through a globally connected network. At the micro-level, many industrial sectors experience absenteeism of the workforce because many are affected or taking care of affected ones at their residences. This leads to a significant drop in operations and production levels, and sustainable performance gets disturbed [4]. The world has been challenged several times by extraordinary pandemics, which left long-term effects on society, businesses, operations, and SCs [5]. Among these ripple effects, 20 to 50 million people died due to the Spanish Influenza outbreak in 1918-1919. Similarly, the Ebola virus also had unmatched effects on all dimensions. These large-scale losses urged the upgrade of disease risk, prevention, and outbreak management facilities, despite the unavailability of cures [6,7]. Notable outbreaks such as SARS, MERS, AIDS, cholera, and malaria have affected society, as well as the economy, having accumulated effects in the billions of US dollars [8]. Moreover, a lot of waste and environment damages are caused every year [9].

In recent years, the frequency and severity of these disasters have been becoming worse due to several factors. World Health Organization [10] has categorized various types of disasters. The potential types which potentially lead to epidemic outbreaks are classified in Figure 1. The emergencies' consequence is pandemics, causing unprecedented losses. All SCs, at a local and global level, get affected and face challenges in ensuring logistic and manufacturing operations continuity [11]. Therefore, it is important to address the diseases under a unanimous framework in the current timeline. A few studies have reported that these epidemics are the consequence of climate change and patterns [12]. Businesses are already experiencing disasters. Recently, they have been hit by the highly contagious, unprecedented, and infectious outbreak termed as COVID-19. It is a novel outbreak causing disturbances to human lives and the circular economy [13].

The unmatched outbreak, COVID-19, was identified from Wuhan's wild food market and reported in late 2019. In the initial phases, China was affected severely and had to reduce economic and industrial activities, along with instigating several lockdowns in different cities. The dependence of the world supply chain on the world's factories was at a huge risk, and activities were reduced significantly. After a short time, cases were reported worldwide and it became a global emergency. The sprawl of COVID-19 affected 216 countries or territories as of 24 June 2020, with 9,110,186 active cases, and 473,061 deaths [14]. A global emergency was announced on 11 March 2020 [15].

The effects of this outbreak have gained the interest of researchers and scholars [5,13,16-28], as well as industrial leaders [29-32], who are working to explore the impacts on SCs under uncertain conditions. Moreover, various dimensions related to the disruptions are being investigated, while industries are reconnoitering points to prepare for digitization to combat forthcoming disruptions. The recent epidemic outbreak has already disturbed business operations on a large scale. Therefore, early detection of disruptions and quick remedial actions can allow industries to lower the impact of current and future shocks. For example, it is recommended to build transparent multitier systems, enhance capacity in logistics, to carry out operations optimization, and improve access to the actual customer to reduce bullwhip effects [33]. Likewise, ref. [34] published the disturbances because of COVID-19 among 94\% of the leading 1000 industrial tycoons. The lessons from previous disease outbreaks, epidemics, and catastrophes also insist on the building of reliable and sustainable system designs [13,35], and there is a framework available which can predict potential disease outbreaks [36]. 


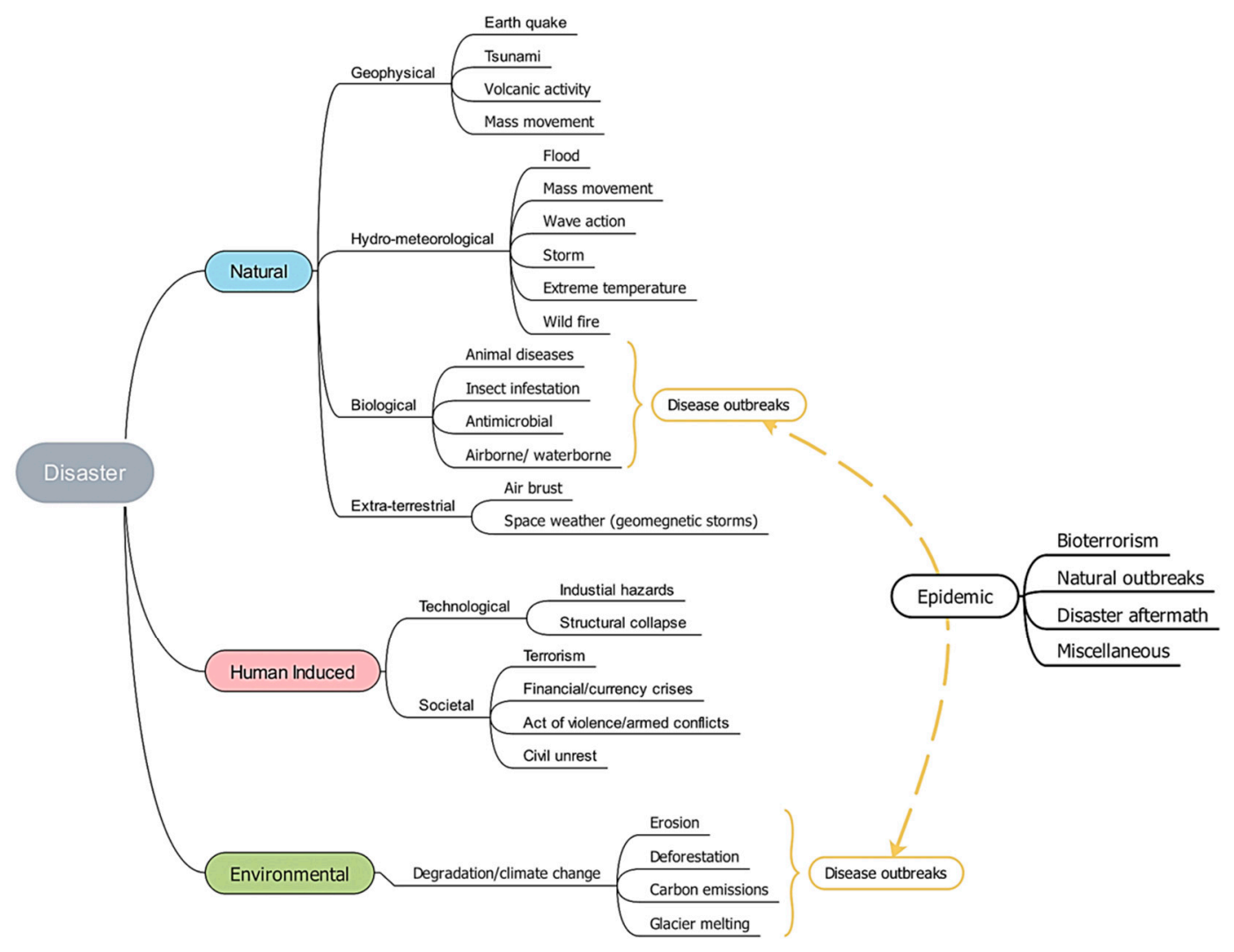

Figure 1. Disaster classification which poses serious threats to global supply chains (SCs). (Source: authors).

Due to this outbreak, severe disorder is caused in smoothly running operations. Many manufacturers had to close their production operations fully, and some reduced them to minimum capacity. The logistics operations linked with fulfilling supply and demands were disturbed due to airport bans, because of restrictions by governments. Similarly, the demand for medical equipment exponentially rose [13]. In the past, strategic decision making and technology integrated with operations and supply chain management have been aided by numerous research works under other epidemic outbreaks. These works were skewed towards resource allocation, procurement and distribution, emergency response, and decision making in network design and relief operation management $[18,23,37,38]$. Much of the prominent research was carried out to support influencers in previous outbreaks related to SC networks and operations management [5,24,37,39-42]. Therefore, there are several potential areas in which work is still needed, and addressing constraints of the current epoch. In the modern world, China has a major share of the daily-use product market, therefore, it is known as the world's factory in the fields of automobile manufacturing, electrical and electronics equipment, medical devices and equipment, textiles, and many more sector. When the virus was first reported in China, therefore, they started fighting it before its cases appeared in other territories [14]. There are two major goals to be considered in these disrupted situations. The first includes ensuring the sustainability of operations and resources, along with labor availability and safety from the disease. The second goal is to shift operations and other activities towards digitally supported systems, upgrading overall reliability. The question of the survival of the SC network gets reduced through alignment with industrial revolution 4.0. Moreover, operations research and management approaches are assisting practitioners in analyzing system limitations, to act suitably, as shown in Figure 2. To equip the SC networks for future shocks, highly digitized system-level flexibility with strong integration is required [22]. 


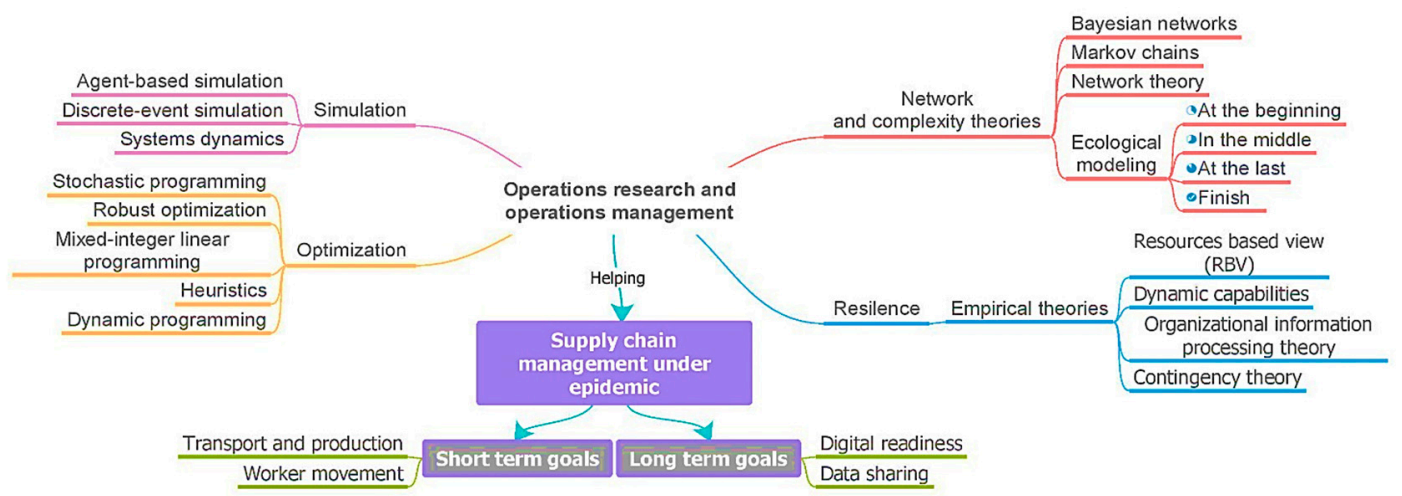

Figure 2. Operations research and operations management helping in supply chain disruption for short-term and long-term goals. (Source: authors).

These tough circumstances have started a debate on the previously available strategies and approaches for the robustness of SC networks. For instance, individual frameworks, such as lean and agile manufacturing, and a resilience and sustainability-focused on maximizing market response rather than ensuring survivability [22,43]. The field of sustainability and viability of operations in SC networks under different uncertain conditions is also being revisited according to current needs [23,24,44]. However, the long-term sustainable solution lies with digitally supported technological help $[45,46]$.

The technological portfolio of industrial systems is being entirely upgraded at the moment, compared to systems in previous epidemic outbreaks. SC disruptions, especially during epidemic outbreaks, before the twenty first century caused huge threats to economies, public well-being, and industrial sustainability. The reasons being, the inadequate availability of disease management and control systems, incapable technological systems to support business operations, and the low reliability of supply chain networks. Recently, developments in decision science have helped to optimize sustainable operations in uncertain environments. These can potentially be extended to cases of epidemic/disasters. For instance, resource allocation in a dynamic environment is a very important domain to be explored. Similarly, new technologies can help in tough situations, through smart production systems in smart cities.

The theme under focus is promising and vital, as well as at the initial phase of development $[24,33,47,48]$. This review article bridges the gap by providing comprehension of SC operations, and aims at the extension of research through open avenues. It will help the related personnel in strategic planning, as well as decision making. Subsequently, considering the paucity of literature on survivability during disturbances, it will connect the dots on the effects of outbreaks on SC. A few research questions are pursued which are cited in later sections. We will develop a baseline for researchers through opening avenues and directions in this niche area to advance SC research.

The article is organized in the following manner. There are four major sections. The first section covers the overview of recent events from a SC disturbance viewpoint. Moreover, it establishes the subject introduction and need for study. In the second section, the process of data collection is mapped. The methodology followed, using a systematic literature review, is discussed in the section. In Section 3, the objectives tackled by experts during previous pandemics and outbreaks are reviewed and categorized from a SC perspective. It continues with a systematic literature review on the viability and sustainability of SCs addressing survivability goals. Section 4 contains open research areas, and future avenues for broadening technological implementation principles and discussion, are regarded. The concepts of modern technologies for viability are introduced and formalized in the subsection of Section 4. At the end, the paper is concluded by summarizing the major findings and outlining future research perspectives. 


\section{Problem Statement and Objectives}

A pandemic like COVID-19 (SARS-CoV-2) is one of the special cases which put our business and supply chain operations at huge risk. These are specifically exemplified by long-term disturbance, ripple effects generated through propagating disruptions, and a highly uncertain environment. Nevertheless, very limited research works have reported on approaches in this direction in a structured manner. The available literature is dispersed among multiple streams and sources. Few reviews could be pinpointed from the perspective of SC under pandemics or outbreaks [39,47]. Despite the scarcity of literature on the correlation of SC survivability and epidemic outbreaks, this research facilitates researchers, influencers, and governments by outlining the overall insights, to consequently form strategies. Epidemic control and related logistics operations were categorized [39] and mapped against operations and SC management [47]. Due to the scarcity of literature in the selected domain, there is an urgent need to frame previous developments in epidemic outbreaks to improve the efficiency and reliability of supply chain networks. Moreover, outlining the sustainability and viability perspectives of supply chains can help decision makers with short-term and long-term risk mitigation and recovery plans. However, this work concentrates on viability and sustainability during ripple effects caused by disasters, or specifically outbreaks. Moreover, the survivability in previous epidemic outbreaks and the works carried out from those perspectives are also focused on. Furthermore, this article maps past emphasis on future research directions in Coronavirus-like epidemic outbreaks. The objectives which are addressed in this research are given below.

- Providing a comprehensive operations management review in pandemics and framing the objectives addressed in epidemic outbreaks.

- Exploring and categorizing supply chain operation objectives solved in the context of previous pandemics, solution methodologies, and their associated implications.

- Identifying supply chain sustainability, viability, and industry 4.0 developments from a pandemic perspective.

- Classifying literature gaps and research extension opportunities to support supply chain practitioners during COVID-19-like pandemics.

- Developing a conceptual integrated framework of supply chain operations management sustainability preparedness, resilience readiness, and digital vigilance.

\section{Research Methodology}

To carry out this research, a systematic literature review (SLR) was carried out. This has a conventional use, mainly carried out in medical and other sciences. Where, it is defined as follows [47]: An efficient and effective technique to summarize the findings of existing literature, gauging the consistency in previously reported studies, confirming that tasks are not unique to the current discussion.

Previously, a SLR has been taken into consideration by several researchers to map various problems from a SC perspective [49-52], and is considered a rigorous method to evaluate research status in any field. It includes several steps, for instance planning (includes research questions, defining the scope and limiting the subjects under their interdisciplinary nature), searching (contains search protocol, relevancy, database selection, reliability), screening (inclusion and exclusion criterion), and extraction (analysis, reporting major studies, insights on existing literature).

\subsection{Planning}

The basic information articles were taken from a wide range of databases, for example, Scopus, Science Direct, Google Scholar, Wiley, Web of Science, and other international forum's websites. In addition to this, to comply with reliability Scopus indexed journals and Scopus database was selected for data collection. From the rigorous literature survey, incidentally, multiple intersections of various supply chain perceptions of epidemic outbreaks, distributed through the literature, have not previously been rationalized. Therefore, 
a considerable and distinct contribution is made by this study by building upon these explicit research questions (RQ):

- RQ1. What is the state-of-the-art in the existing literature related to SC disruptions, especially during epidemic outbreaks?

- RQ2. What are the unexplored areas and open questions to combat these effects in the field of SC?

The questions were designed in a way that the problem is specified in the form of questions. The answers to the above questions were expected from this research paper. The most important and major support, through this study, will comprise an insight into the research agenda for SCs at the time of disasters or epidemic outbreaks; moreover, a systematic investigation of the literature on epidemic outbreaks and supply chain operations. In addition to this, several open questions and future research avenues were identified that can be explored in the extension of the existing body of knowledge.

\subsection{Searching}

To comply with objectivity and reliability, the research protocol is provided in Table 1. The Scopus database was employed to import potential data. It was used in the literature review works $[43,53]$. All the articles selected were from peer-reviewed journals indexed by Scopus. Keywords were used to find out the most relevant papers, such as "supply chain", "operations management", "logistics" as a general protocol for SC and operations management $(\mathrm{OM})$ field delimitation. Whereas specifically "sustainability", "ripple effect" and "survivability" were used. The scope of the search was limited by defining Boolean operators (AND, OR, AND NOT) to search in a precise manner. The viability of SCs during tough times and looking up sustainability for the future specified a focus on survival. Therefore, both terms, viability and sustainability, were explored to keep the discussion wide, to include various perspectives. The period was selected as 2010-2020, to view recent developments in the field after certain large disasters. The search comprised three steps: first accessing for sustainability, secondly viewing from the perspective of ripple effects, and thirdly concerning the risks involved in future outbreaks.

Table 1. Systematic literature review protocol.

\begin{tabular}{|c|c|c|}
\hline & Research Protocol & Description \\
\hline $\begin{array}{l}\text { Search base } \\
\text { plan }\end{array}$ & $\begin{array}{l}\text { Databases } \\
\text { Publication type } \\
\text { Language } \\
\text { Year range }\end{array}$ & $\begin{array}{c}\text { Scopus database } \\
\text { Peer-reviewed journal articles indexed by Scopus } \\
\text { English } \\
\text { 2010-2020 (exploring streams of last } 10 \text { years) }\end{array}$ \\
\hline $\begin{array}{l}\text { Directing } \\
\text { features }\end{array}$ & $\begin{array}{l}\text { Search terms } \\
\text { Search term in titles, abstracts, } \\
\text { keywords }\end{array}$ & $\begin{array}{c}\text { Titles, abstracts, keywords } \\
\text { ("Supply chain" OR “operations management" OR “logistics" AND } \\
\text { "sustainability" AND “disaster" OR “epidemic" OR "pandemic" } \\
\text { OR “outbreak") } \\
\text { ("Supply chain" OR “operations management" OR “logistics" AND } \\
\text { "Ripple effect” AND “viability" OR "sustainability") }\end{array}$ \\
\hline $\begin{array}{l}\text { Limiting } \\
\text { factors }\end{array}$ & $\begin{array}{l}\text { Inclusion criteria } \\
\text { Exclusion criteria }\end{array}$ & $\begin{array}{l}\text { Research articles presented on any disaster, specifically epidemics } \\
\text { Research articles with general focus, discussing disasters, outbreaks } \\
\text { without the context of supply chain and/or operations management }\end{array}$ \\
\hline Analysis & $\begin{array}{c}\text { Data extraction, analysis, } \\
\text { and synthesis }\end{array}$ & Supported by VOS viewer to visualize the streams and detailed analysis \\
\hline
\end{tabular}

\subsection{Screening}

For objectivity purposes, the following inclusion and exclusion criteria were defined. We determined the criteria. 


\subsubsection{Inclusion}

As the objective of this study was to get an insight into the impacts of epidemic outbreaks on SCs and methods, OM helped from this perspective. Therefore, only those papers were included which presented the problems associated with epidemic control and effects in the field of operations or supply chain management. In addition to this, only peer-reviewed journal articles were included, except for a few other relevant sources which were necessary to answer the developed research questions of this study.

\subsubsection{Exclusion}

Articles related to healthcare management and clinical trials, humanitarian and commercial logistics and supply chain management were out of the scope of this study. Moreover, papers written in languages other than English were also excluded. The scope was further specified to "Business, Management, and Accounting" and "Engineering" and "Decision sciences".

\subsection{Extraction}

Initially, the impact of different outbreaks or diseases reported on a large scale were discussed, concerning supply chain, logistics, or operations management, along with major methods. For information extraction, the Scopus database integrated with VOS viewer [54] was employed, and for subsequent analysis, for instance co-occurrence analysis (VCA; www.vosviewer.com (accessed on 30 January 2020)) [55]. This methodology helped to analyze the literature objectively; algorithmically by retrieving the articles; classifying and accumulating key terminologies in distinct clusters; and specifying future research directions and avenues. For the systematic evaluation of the literature, the protocol is defined for objectivity in Figure 3. However, Figure 4 presents year wise publication analytics.

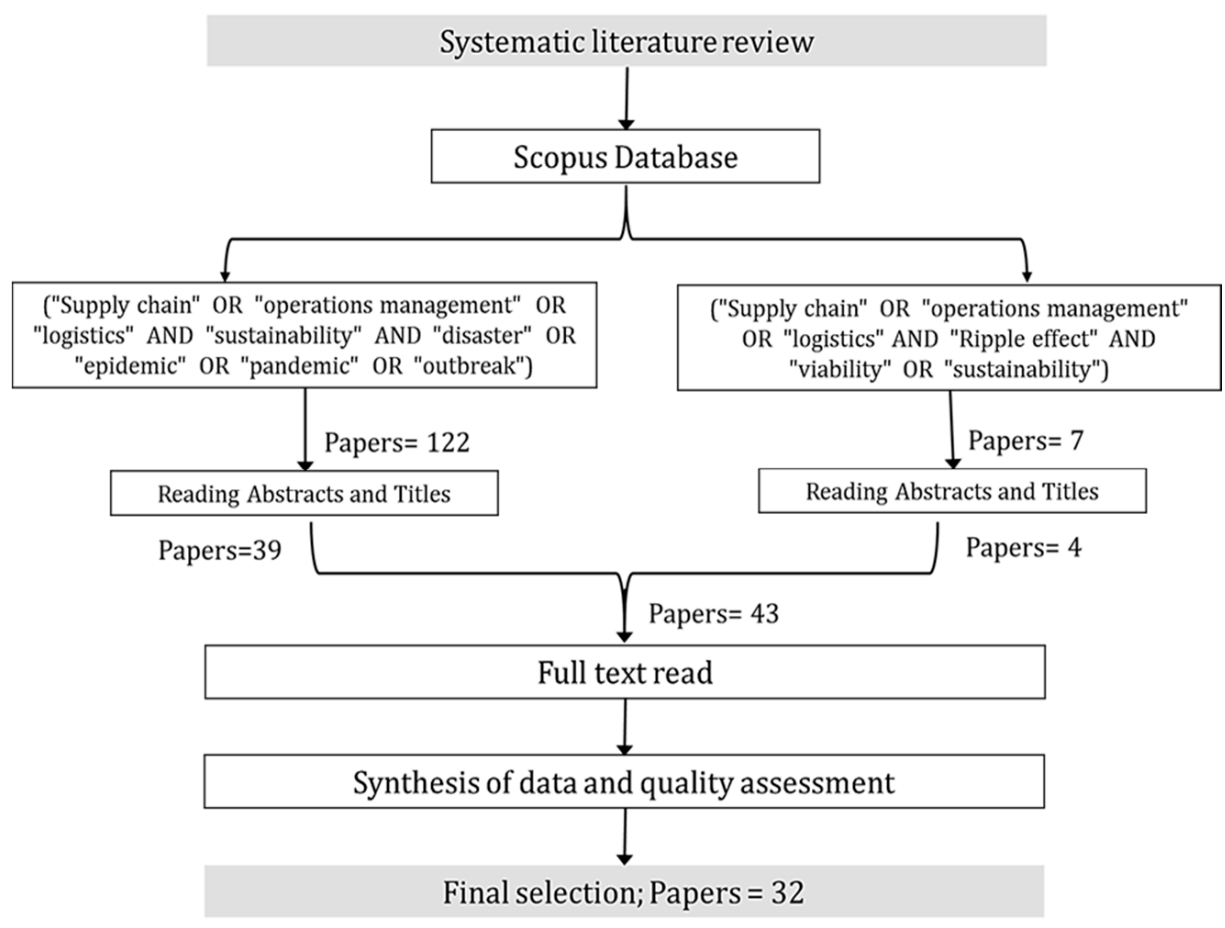

Figure 3. Protocol for the systematic literature review. 


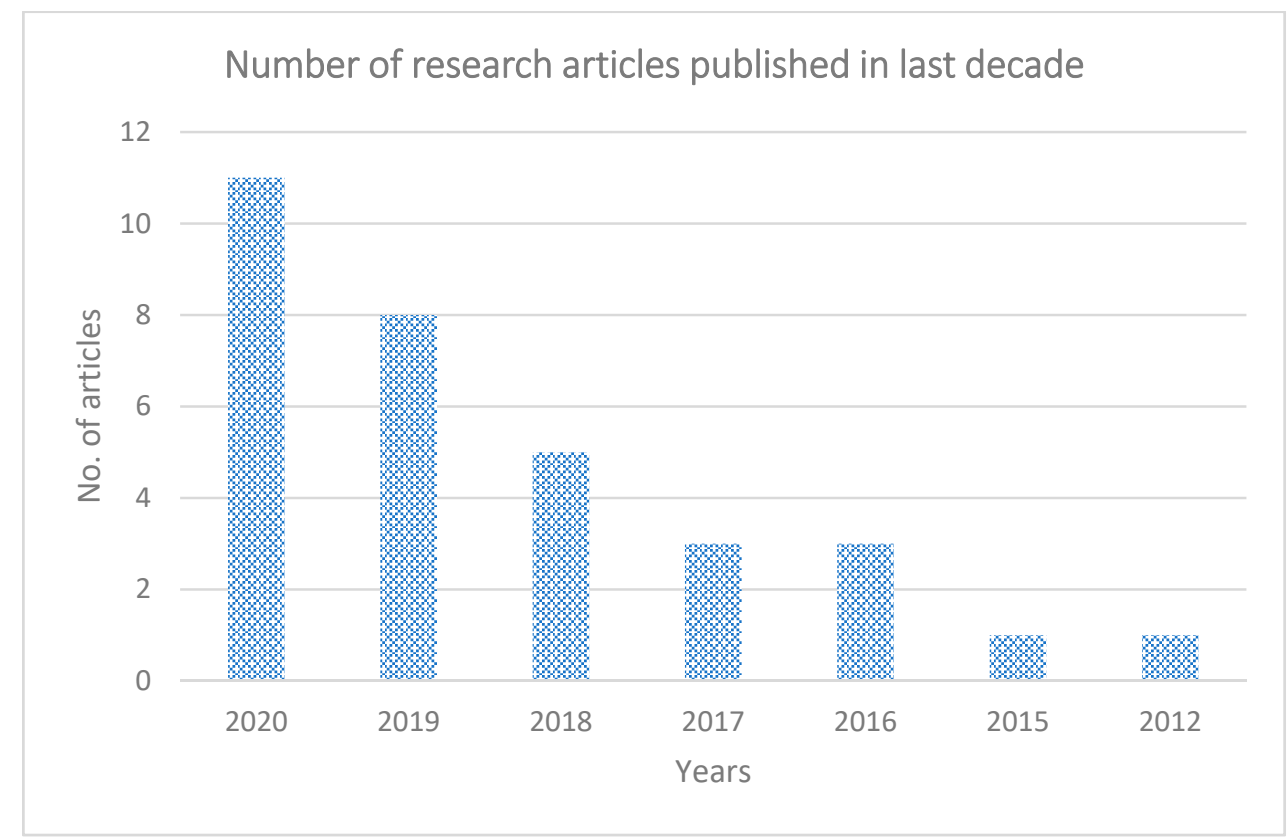

Figure 4. Year-wise distribution of research articles taken under consideration.

\section{Discussion on the Findings}

This section will cover journals of selected publications, the categorization of previous epidemic outbreaks and SC implications, multiple correspondence analysis, and SC sustainability and viability during outbreaks.

\subsection{Publications in Journals}

A journal chart is displayed in Table 2 to show the distribution of research studies concerning journals. The journals with a focus on operations and supply chain management, logistics, and production represent a major portion of the selected publications. These include the Annals of Operations Research, Journal of Cleaner Production, International Journal of Production Research, and the Journal of Humanitarian Logistics and Supply Chain Management, whereas some journals with a management science focus also spanned publications on the selected area, such as Management Decision; the International Journal of Mathematical, Engineering and Management Sciences; IEEE Engineering Management Review; the and Journal of Enterprise Information Management.

Since this study mainly focuses on epidemic effects on operations, supply chains, and logistics, therefore, journals on supply chain and logistics are greater in number. Similarly, COVID-19's impacts are included from a similar perspective, and open questions supported with literature gaps are also suggested to extend research studies in this direction. A dedicated study on the impacts of outbreaks, devoted to SC, was carried out using the Scopus database through "disease" OR "outbreak" OR "epidemic" AND "supply chain" OR "logistics" OR "humanitarian relief" keywords. The impact related studies spanned over 30 publications, related to Influenza, Ebola, Cholera, Malaria, Smallpox, and COVID-19. Whereas, with a survivability and sustainability emphasis, see Table 1 , $37.5 \%$ of the publications were from the Annals of Operations Research, Journal of Cleaner Production, and the International Journal of Production Research. These journals published related impacts concerning different agendas over time. However, it is noted that the journals dedicated to logistics, production, and systems had limited content on the selected topic (one article till July 15), such as Transportation Research Part E, International Journal of Logistics Research and Applications, International Journal of Sustainable Transportation, Production and Operations Management, International Journal of Operations and Production Management, Intelligent Systems Reference Library, and Global Journal of Flexible Systems Management. 
Table 2. Publications in journals.

\begin{tabular}{cc}
\hline Sources & Articles \\
\hline Annals of Operations Research & 5 \\
Journal of Cleaner Production & 4 \\
International Journal of Production Research & 3 \\
Transportation Research Part E & 2 \\
Journal of Humanitarian Logistics and Supply Chain Management & 1 \\
Production and Operations Management & 1 \\
Management Decision & 1 \\
International Journal of Operations and Production Management & 1 \\
International Journal of Logistics Research and Applications & 1 \\
International Journal of Mathematical, Engineering and Management Sciences & 1 \\
Engineering Applications of Artificial Intelligence & 1 \\
International Journal of Sustainable Transportation & 1 \\
Global Journal of Flexible Systems Management & 1 \\
Corporate Social Responsibility and Environmental Management & 1 \\
Benchmarking & 1 \\
Journal of Risk Research & 1 \\
Journal of Enterprise Information Management & 1 \\
Natural Hazards Review & 1 \\
International Journal of Safety and Security Engineering & 1 \\
Intelligent Systems Reference Library & 1 \\
Economic and Labour Relations Review & 1
\end{tabular}

\subsection{Categorization of Previous Epidemic/Disease Outbreaks and SC Implications}

To get an understanding of the impacts of previous outbreaks, a rigorous literature review is summarized in Table 3, categorizing the available research on different epidemics' effects on the performance of SCs. The content analysis was carried out by focusing on the epidemic and objectives studied in those publications, the problem-solving approaches, and the related implications recommended and proposed in those pandemic situations. 
Table 3. Pandemics and the objectives to resolve their impacts on SC.

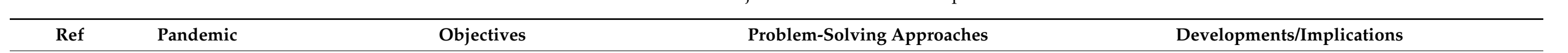

- $\quad$ Resource allocation during the outbreak.

- deterministic model.

- logistics model especially for medical resources.

- contractual model for vaccine procurement and distribution under an inefficient system.

- Investigations on transportation infrastructure and logistics policies for medicine distribution.

- Drug distribution model and redistribution of resources during a pandemic.

[56-69] Influenza

- Epidemic logistics model to control the disease.

- $\quad$ Food distribution planning.

- Optimization of patient and resource allocation.

- Vaccine distribution to selected groups with a minimum distance coverage focus.

- Logistics challenges to public health care response through international support.

- Stating the effects of the disease on SC, logistics, vaccine procurement, distribution, and related challenges.

- Food distribution and risk of propagation of disease.
- Qualitative analysis of yearly published reports, WHO announcements, recommendations, documents of disease control departments.

- Brainstorming and devising a conceptual roadmap.

- Game theory and/or optimization.

- Case study.

- Mathematical modelling/exact method approach.

- Optimization heuristics and/or case study.

- Agent-based simulations and/or mixed-integer linear programming.

- Non-linear programming.

- Simulation and/or case study.

- Secondary data analysis.

- $\quad$ An integrated model for suppliers and retailers was recommended to make use of cutting-edge technology. Moreover, traceability measures can improve logistics performance.

- To combat the epidemic, adequate involvement of policymakers and government officials is required to develop logistics, operations, and SC capabilities.

- A rigorous focus is retained on the coordination of influencers to combat vaccine shortfalls and to reduce social costs by distributing them to several partners.

- However, logistics activities play a vital role in outbreak control through necessary medication and preventive essentials. Based on this, the response to outbreak control through international coordination is possible.

- The outbreak elimination is also dependent on public health care officials' decisions to disseminate vaccine through effective network design.

- To address the capacity issues, voluntarily quarantine helped industries such as food industries, which were running at half capacity. Furthermore, the proceedings to take control of the outbreak dynamically were carried out while taking logistics factors and disease propagation into account. Management of dispersed resources and logistics infrastructure plays a vital role in managing the outbreak.

- $\quad$ Epidemic logistics model, including dealing with the constraints of treatment centers such as geographical variables, the changing aspects of infected locations, and the effect of resource allocation.

- Logistics modelling for resources distribution to - Mixed-integer linear

Disease promotion through air-travel and defining the role of aviation infrastructure.

[70-72] Ebola
- Configuring treatment places and comparing strategies for affected ones programming/case study.

- Secondary data analysis

- Heuristics.

- Dynamic programming
- Efficient developments in passenger screening were devised against limited airport infrastructure to avoid disease propagation. The resource allocation approach should depend on the dynamic evaluation of the complete system and disease propagation status backed through a strong logistics control system. 
Table 3. Cont.

\begin{tabular}{|c|c|c|c|c|}
\hline Ref & Pandemic & Objectives & Problem-Solving Approaches & Developments/Implications \\
\hline$[37,73-75]$ & Cholera & $\begin{array}{l}\text { - } \quad \text { Response to the epidemic outbreak. control } \\
\text { policies and the emergence of health facilities } \\
\text { - } \quad \text { data-driven model } \\
\text { - } \quad \text { model based on the distance for facility location } \\
\text { decisions in the context of humanitarian } \\
\text { response. } \\
\text { model based on resource constraints such as } \\
\text { facilities location, staff, size and so on }\end{array}$ & $\begin{array}{l}\text { - } \quad \text { Haddon matrix } \\
\text { - } \quad \text { Secondary data analysis } \\
\text { - } \quad \text { Mixedel/netwod planner } \\
\text {-integer linear programming }\end{array}$ & $\begin{array}{l}\text { - Through a Haddon matrix, a framework provides } \\
\text { comprehension on logistics during multiple phases of a } \\
\text { disaster, such as pre-, during, and post-event for } \\
\text { humanitarian purposes. The focus was shifted towards } \\
\text { empowering medical staff as a part of SC to make } \\
\text { resource allocation in emergency stages more effective. } \\
\text { Individual's behavior to make logistics more effective is } \\
\text { important in humanitarian SCs. The effective resource } \\
\text { allocation of limited SC supplies and response to the } \\
\text { epidemic, multiple types of resources, and their } \\
\text { consecutive demand should be assessed. }\end{array}$ \\
\hline [76] & Malaria & $\begin{array}{l}\text { Drug distribution strategy under strategic and } \\
\text { tactical aspects }\end{array}$ & - Markov decision approach & $\begin{array}{l}\text { - Effective transportation planning can reduce costs and } \\
\text { shortages in medicine and vaccine procurement and } \\
\text { distribution. } \\
\text { Several challenges are identified during implementation } \\
\text { phases, such as inadequate communication, fragile } \\
\text { implementation efforts and engagement by government } \\
\text { and other authorities, and poor infrastructure of } \\
\text { transportation (logistics). }\end{array}$ \\
\hline [77] & Smallpox & $\begin{array}{l}\text { - Response to the disaster through SC emergency } \\
\text { for large scale vaccination }\end{array}$ & $\begin{array}{l}\text { - Operations research/linear } \\
\text { programming }\end{array}$ & $\begin{array}{l}\text { The emergency network design influences on disease } \\
\text { control and management in socio-economical activities. } \\
\text { The research contributed to outbreak propagation control } \\
\text { and resource distribution model assisting in epidemic } \\
\text { control and management. }\end{array}$ \\
\hline$[5,22-24]$ & COVID-19 & $\begin{array}{l}\text { - Investigation of SC resilience and robustness } \\
\text { strategies } \\
\text { - Analysis of intertwined SC networks for } \\
\text { survivability: the perspective of digital SC } \\
\text { Prediction of impacts ranging from operations } \\
\text { disturbance to economic activity. }\end{array}$ & $\begin{array}{l}\text { - } \quad \text { Simulation/case study } \\
\text { - } \quad \text { Same theory } \\
\text { industrial newsletters and, health } \\
\text { and economic forums }\end{array}$ & $\begin{array}{l}\text { - Unmatchable disruptions to SCs are reported. Different } \\
\text { developments to accurately predict the effects on various } \\
\text { SCs, ranging across several time zones, to support the } \\
\text { performance and for mitigation. } \\
\text { The disruption is pushing industrial leaders to test } \\
\text { different resilience strategies to combat the effects. } \\
\text { For this, analysis of interconnected and resilient } \\
\text { networks also assures survivability and sustainability in } \\
\text { COVID-19-like disruptions over a long-term tenure. }\end{array}$ \\
\hline
\end{tabular}


Table 3. Cont.

\begin{tabular}{|c|c|c|c|c|}
\hline Ref & Pandemic & Objectives & Problem-Solving Approaches & Developments/Implications \\
\hline [78-86] & $\begin{array}{c}\text { General } \\
\text { epidemic } \\
\text { manage- } \\
\text { ment/control }\end{array}$ & $\begin{array}{l}\text { Development of a model to enhance vaccine } \\
\text { procurement and reduce associated social costs. } \\
\text { Vehicle trip network structure development } \\
\text { concerning passenger density. } \\
\text { Vaccine distribution model in high constraints } \\
\text { of logistics. } \\
\text { Experts view on efficient response to an } \\
\text { epidemic outbreak. } \\
\text { - Emergency model for SC networks to address } \\
\text { fluctuations in demand during the pandemic. } \\
\text { Policies to eradicate effects of pandemic under } \\
\text { uncertain conditions. }\end{array}$ & $\begin{array}{l}\text { - } \quad \text { Artificial intelligence algorithms } \\
\text { such as machine learning, genetic } \\
\text { algorithms. } \\
\text { - } \quad \text { Monte-Carlo simulation. } \\
\text { - } \quad \text { Exploratory modelling analysis. } \\
\text { A multi-objective stochastic } \\
\text { programming model. } \\
\text { - } \quad \text { Panel discussion/focus group. } \\
\text { - } \quad \text { (SIR) model. } \\
\text { - Secondary data analysis }\end{array}$ & $\begin{array}{l}\text { - The option contract model was proposed to assist } \\
\text { suppliers through demand optimization to reduce } \\
\text { procurement and social costs. A model to identify } \\
\text { infectious vehicles to support logistics and SC, and to } \\
\text { avoid risky trips, was developed. Whereas, distance for } \\
\text { optimized logistics protocols remains a challenge for } \\
\text { effective resource allocation. } \\
\text { Emergency medicine distribution and long periods of } \\
\text { delay also contribute to increasing uncertainty. } \\
\text { An effective way to resolve these issues is proposed } \\
\text { through an integrated model employed in SCs to } \\
\text { minimize shortages, an adequate flow of medicines and } \\
\text { other resources in an integrated manner. Moreover, } \\
\text { effective identification of an infectious public system can } \\
\text { help to modify resource distribution plans with disease } \\
\text { propagation. }\end{array}$ \\
\hline
\end{tabular}


Moreover, the focus of these publications was towards providing optimization models for resource allocation, logistics planning such as vaccine procurement and distribution, and medication facility location. A few were focused on the minimization of disease propagation through various means, such as airports and strategies to restrict disease spread with a dynamic assessment of the pandemic. For an Influenza outbreak, ref. [56] proposed a deterministic model to manage disaster under limited and distributed resources, considering uncertain demand during the time of the epidemic. Whereas, ref. [57] proposed a time series model, through minimizing forecast error for shipping and resource allocation. Ref. [58] analyzed the inefficiency and imbalance of vaccine impacts, and proposed a contractual model to eliminate shortages. In addition to this, epidemic propagation needs effective infrastructure to restrict global dispersion of disease through airports [59,71]. To deal with vaccine distribution problems in an Influenza outbreak, ref. [60] suggested the distribution of medicines relative to disease progression in a dynamic manner. Ref. [67] contributed food distribution planning in the network, facility location, and resource distribution. Refs. [68,69] supported health care decision-makers related to vaccine storage facility location selection, resource allocation, and distribution plan efficiency, to eliminate Influenza disease. Ref. [66] shed some light on the importance of logistics during an epidemic outbreak like Influenza. Refs. [63-65] proposed a conceptual model, proceeding from the role and coordination of government and manufacturers (directly related to resources such as medicine, food, safety equipment and so on). They concluded that without having adequate coordination, social accomplishments cannot be utilized to reduce the effects of the disease. Similarly, ref. [62] analyzed food distribution issues and suggested using cutting-edge technology, such as traceability with an integrated supplier-retailer model, during a bird flu disease outbreak.

To control Ebola outbreaks, ref. [70] introduced and validated a logistics model under the geographical dynamics of regions and support, through resource distribution constraints. It provided valuable information about the distribution center's facility location. Ref. [72] highlighted the importance of adequate planning in resource allocation to fight Ebola disease efficiently. Where cholera is concerned, refs. [37,73,75] proposed a humanitarian logistics model to help in all stages of the disaster. Additionally, a data-driven SC model was proposed to address emergency conditions (including medical staff empowerment) and relative resource allocation. For Malaria and Smallpox diseases, an efficient transportation model was proposed for the reduction of medical supply shortages. Furthermore, the configuration of how an emergency SC network reacts during a pandemic was considered, concerning social and economic activities.

Whereas the impacts of COVID-19 and ways to deal with these issues have not been frequently studied yet. The pandemic has had unmatched impacts on global SCs by severely disturbing smoothly run operations. Refs. [5,23] tried to measure the impacts through simulating artificial disturbances at different potential places, and evaluated the impact on global SCs. The authors tried multiple cases at different time horizons and evaluated intertwined SCs, which resulted in a promising approach for viability and survivability in deeply uncertain environments. However, an additional focus on flexible and buffer supported real-time SCs was highlighted to increase the resilience and robustness of SC networks. These recent studies put some light on this disruption, but do not mean that an adequate level of research findings and maturity has been reached in this area. However, SC experts are encouraged to develop new findings using well-equipped technologies, techniques, and approaches (some are mentioned in Figure 2 and so on) to adequately understand the impact on SCs in different sectors. A strong data analytics analysis can be deployed on real-time data to support logistics, operations management, and sustenance, and emergency conditions can be assessed through social media support. This can help practitioners to evaluate and take decisions to minimize the impacts on SCs.

Generally, multiple research studies have been conducted to minimize the effects on SC areas without specifying any disease or epidemic. Ref. [83] developed an optimized model to meet the demand for a vaccine by minimizing demand forecast error, and social 
and procurement costs. Refs. $[81,82]$ developed logistics research to ease planning and distribution of resources, ultimately avoiding risky trips. Ref. [80] developed insight into the importance of adequate resource distribution to combat disease outbreaks. Refs. [78,79] highlighted the robustness of SCs to ensure adequate flow of supplies, and to minimize shortages by not letting delays create uncertainty.

\subsection{Multiple Correspondence Analysis}

To analyze and establish a conceptual map on the selected domains based on the dataset, multiple correspondence analysis was carried out, and displayed in Figure 5. It is an effective technique for reducing contents and developing a conceptual map [47]. It is a two-dimensional technique that constructs a graphical map of the distribution of word similarities in the data set. These words were acquired from "keywords" and "titles" of the references considered for analysis. The frequency of the words used in the publications determines the size of the circle and text, whereas the color represents different clusters. The keywords "sustainability", "disasters", "supply chains", "supply chain management" and "resilience" were easily identifiable and confirmed the research trends in particular areas. However, other words were displayed as emerging research areas in the SC field.

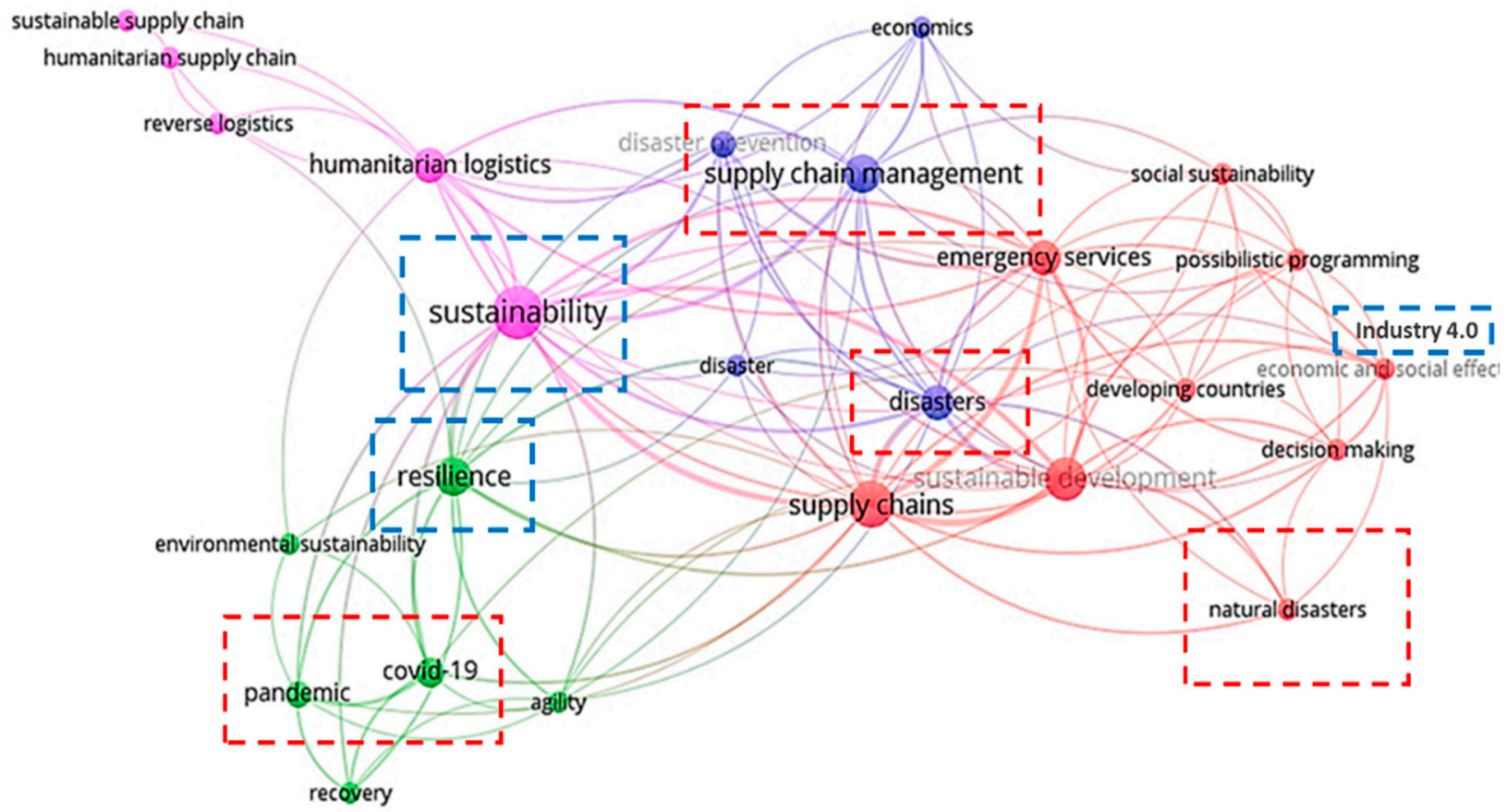

Figure 5. Conceptual map generated through multiple correspondence analysis.

Moreover, "COVID-19", "pandemic", "recovery", "natural disasters", "humanitarian supply chain", and "humanitarian logistics" were also interesting topics for recent scenarios. As represented by the correspondence analysis, "emergency services" recommends areas of effective and efficient resource allocation and logistics planning. As a consequent "resilience", "disasters", and "decision making" indicated emerging themes of the research. In this research study, "sustainability", "pandemic", "disasters", "supply chain", and "emergency services" were visible as impact themes, and were focused to gather the answers to the research questions from the scarce literature. Our study advocates the use of these themes to evaluate the impacts of epidemics and their effects on SCs. From Figure 6, a multiple co-occurrence analysis of the countries of authors affiliation was carried out. The countries "France", "Germany", "United States", "China", "Iran", and "India" contributed more to the research on the selected domain. The size of the circle and text represents the frequency of repetition of the countries in the articles. 


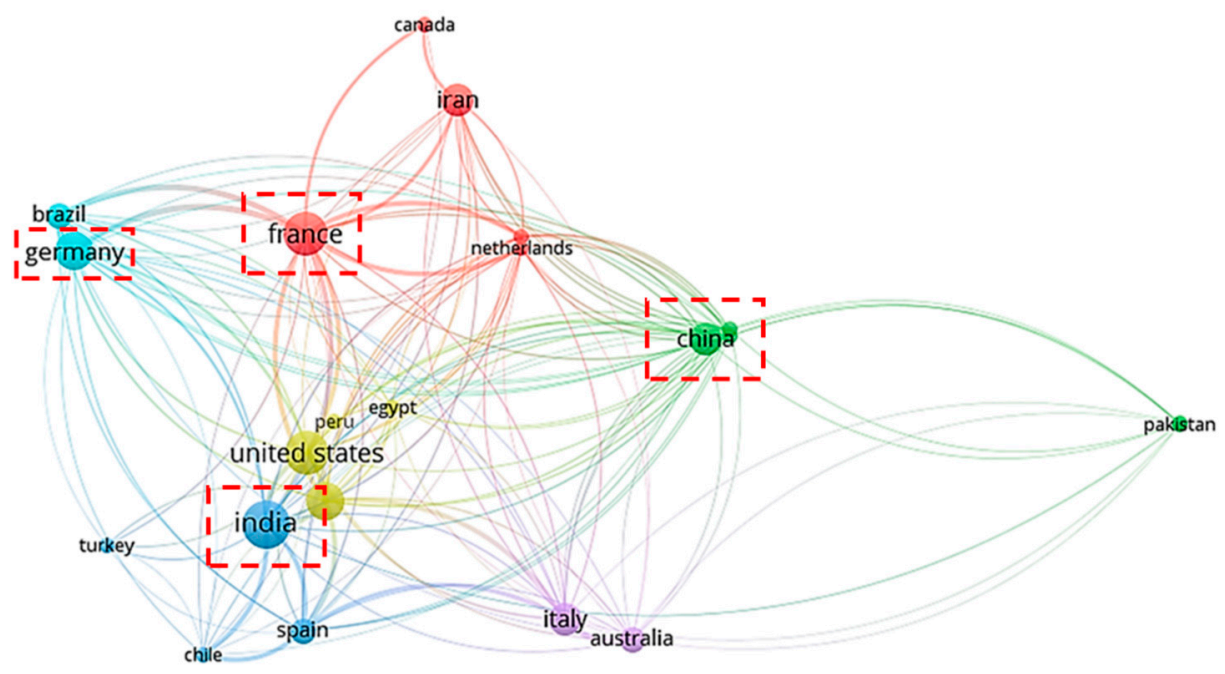

Figure 6. Multiple co-occurrence analysis of the main countries contributing to the selected research area.

\subsection{SC Sustainability and Viability during Disasters/Outbreak Produced Ripple Effects}

The categorization of the publications was carried out for the year of publishing, as shown in Figure 4. Moreover, the countries of the authors working in a similar context are illustrated in Figure 6. More than $80 \%$ of the articles were from the last three years 2018-2020. Furthermore, the selected articles discussed the strategies, models, frameworks, and guidelines for supply chains to avoid disruptions, as well as how to effectively manage risks, make the transition to Industry 4.0, and sustain the developments.

However, some studies approached disasters, epidemics, or outbreaks differently. For instance, ref. [87] extended the investigation on humanitarian crisis, being foreseen because of COVID-19's disruption. Regarding the features of the publications discussed in Table 4, "Area of application" is related to the domain in which the problems are discussed; whereas "Lines of research" is the niche aspect of that research study; "Key contribution" is briefly discussed, which contributes the tangible output. Specifically, "Supply chain risk management" is covered by $[24,88,89]$ several studies addressing risk to SCs at different levels. "Disaster management" and aftermath effects are addressed by [9,90-92]. The transition to "Industry 4.0 " is supported by several studies, to make SCs more interconnected to combat future disruptions [22,43,93-97].

Lastly, several interesting approaches are highlighted related to "Supply chain/Logistics/ Operations implications" in response to disturbances. Recently, ref. [23] presented the disruptive effects of COVID-19 on SCs and simulated the situation through various variables. Consequently, decision-makers are supplied with multiple models, frameworks, and technologies to gauge the effects of the current epidemic and restore the overall SCs and confirming their survivability. Moreover, it has been well demonstrated that SC performance response relies on the scale and timing of the disruption's spreading, and not on the upstream disruption duration. Ref. [47] identified the positive effects of disruption as an opportunity to repurpose and renew SCs responses (upstream and downstream sides) to an epidemic when the disruption is simultaneous. 
Table 4. Different aspects addressed to improve SC performance in the context of disasters/disruptions/outbreaks.

\begin{tabular}{cccc}
\hline Lines of Research & Ref. & Area of Application Contribution
\end{tabular}

\section{Sustainability I Survivability}

Examining impacts on the economic and labor market to build sustainable societies

[87] COVID-19: Humanitarian crises

"Leave no-one behind" agenda is the future, as COVID-19 might be the portal to achieve sustainable development goals more effectively through a greener, ecologically concerned, and sustainable global version. Developed nations are concerned with minimizing the reliance on long transitional supply chains and diversifying the sources of imports, as well as increasing domestic manufacturing capabilities.

Operations and supply chain management approaches to support SCs during epidemic outbreaks

[47] Operations management: Supply A framework to support SCs in the time of epidemic outbreaks based on digitalization of processes, systems and structures, preparedness and recovery against ripple effects under the sustainable capabilities development goal was proposed.

A relief logistics network model considering the strategic and tactical planning issues of facility location, procurement, and resource allocation was proposed, considering the costs of the preparedness and response phases and ensuring social welfare, along with taking care of the ecological impacts of the packaging of relief goods, and CO2 emissions in transportation routes. The proposed model works in pre- and post-disaster phases.

Sustainable humanitarian relief

logistics in different stages of disaster

[98] Operations management

Humanitarian supply chains focusing on social sustainability considering the environmental impact

[99] Green humanitarian logistics and

A framework for green humanitarian supply chain management was developed which identifies the contingency factors related to stakeholders, the field of activity, and organizational management.

Decision support system for a

sustainable humanitarian supply chain

[100] Humanitarian supply chain and

Large scale disaster waste

management under uncertain

Master planning decision support system for managing a sustainable humanitarianism against key parameters such as effectiveness, efficiency, local empowerment, and pollution reduction.

environment

[9] Disaster management

A model was proposed considering economic objectives (total waste processing cost),

environmental objectives (greenhouse gas emissions from waste processing facilities), and social objectives (job opportunities generated).

Green product development (reducing waste, recyclable products) is an effective way to manage green supply chains, as well as ecological aspects (carbon management, eco-design, mutual

Drivers of sustainable supply chain management in industrial sectors

[101] Supply chain management responsibility towards environment, reducing hazardous effects of activities) in a sustainable supply chain management (optimal energy consumption, reduced production and environmental costs).

The response of the supply chain to

[102] Supply chain management:

It was found that responding to natural disasters requires companies to reorganize their natural disasters

Sustainability strategies towards sustainability and to develop new practices such as food safety, organic production, and social responsibility

Sustainable blood supply chain management under uncertainty
A model was proposed for a multi-period and multi-objective sustainable blood supply chain with uncertain data due to an uncertain condition during a disaster and after, considering donor groups, blood collection facilities, distribution centers, and hospitals as the demand points. 
Table 4. Cont.

\begin{tabular}{lll}
\hline \multicolumn{1}{c}{ Lines of Research } & Ref. & \multicolumn{1}{c}{ Area of Application } \\
\hline Sustainability I Survivability & & \\
\hline $\begin{array}{l}\text { Reverse logistics in humanitarian } \\
\text { operations }\end{array}$ & {$[104]$} & $\begin{array}{l}\text { Humanitarian supply chain and } \\
\text { logistics }\end{array}$ \\
\hline
\end{tabular}

Risk-based system for a sustainable textile supply chain $\begin{array}{ll}\text { [105] Supply chain management: } & \text { Sustainability }\end{array}$
Developing commercial practice in the aftermath of a disaster or emergency is not

comprehensively addressed by the reverse logistics based on the triple bottom line. Greenfield opportunities were highlighted for the support of host governments, aid agencies, donors, and most important of all, the affected populations.

A multi-criteria decision support system was proposed to evaluate the risks of different textile materials and the corresponding suppliers using sustainable development criteria, such as environmental protection, recycling capacity, energy-savings, human health and safety, and social impacts.

\section{Industry 4.0 I Digitalization}

\section{Operations management helping to} build efficient, resilient,

and sustainable capabilities

Digital inclusion for resilient

Digital inclusion for resilient
agriculture supply chains

Internet of things (IoT) driven sustainable food supply management

Sustainable supply chain management for disaster resilience with the aid of big data

Reconfigurable supply chain

Supply chain resilience and sustainability

Flexibility in manufacturing for supply chain and service operations
Operations management: Transition to Industry 4.0

Several approaches have been effective to deal with the problems of material, information and financial flows. To achieve sustainable and reliable performance in the Industry 4.0 epoch, industries must look forward by deploying cutting edge technologies such as digital twins, blockchain, big data analytics, artificial intelligence, virtual reality, and so on to ensure connectivity, clarity, and continuity for building reliable capabilities.

Digital transformation was proposed to developing countries for building resilient and sustainable post-COVID-19 supply chains.

A structured Fuzzy-TISM model was proposed to ensure sustainability and food security by reducing food loss and wastage across distribution channels.

[96] Industry 4.0; IoT

It was concluded that swift trust, information sharing, and public-private partnerships are critical enablers of resilience in supply chain networks.

The framework of a reconfigurable supply chain was introduced to operate in highly vulnerable environments, dynamic supply chain meta-structures, and dynamic autonomous services.

A simulation-based model identified that sustainable single-sourcing enhances the ripple effect, whereas facility strengthening mitigates the ripple effect and enhances sustainability. It also builds that a reduction in storage facilities in the supply chain downstream during disruption is risky, as facilities increases sustainability

Certain challenges were identified to improve efficiency and resilience in manufacturing, services, and supply chain systems in the context of flexibility drivers, such as disruption risks, digitalization and smart operations, sustainability and closed-loop supply chains, and supplier integration. 
Table 4. Cont.

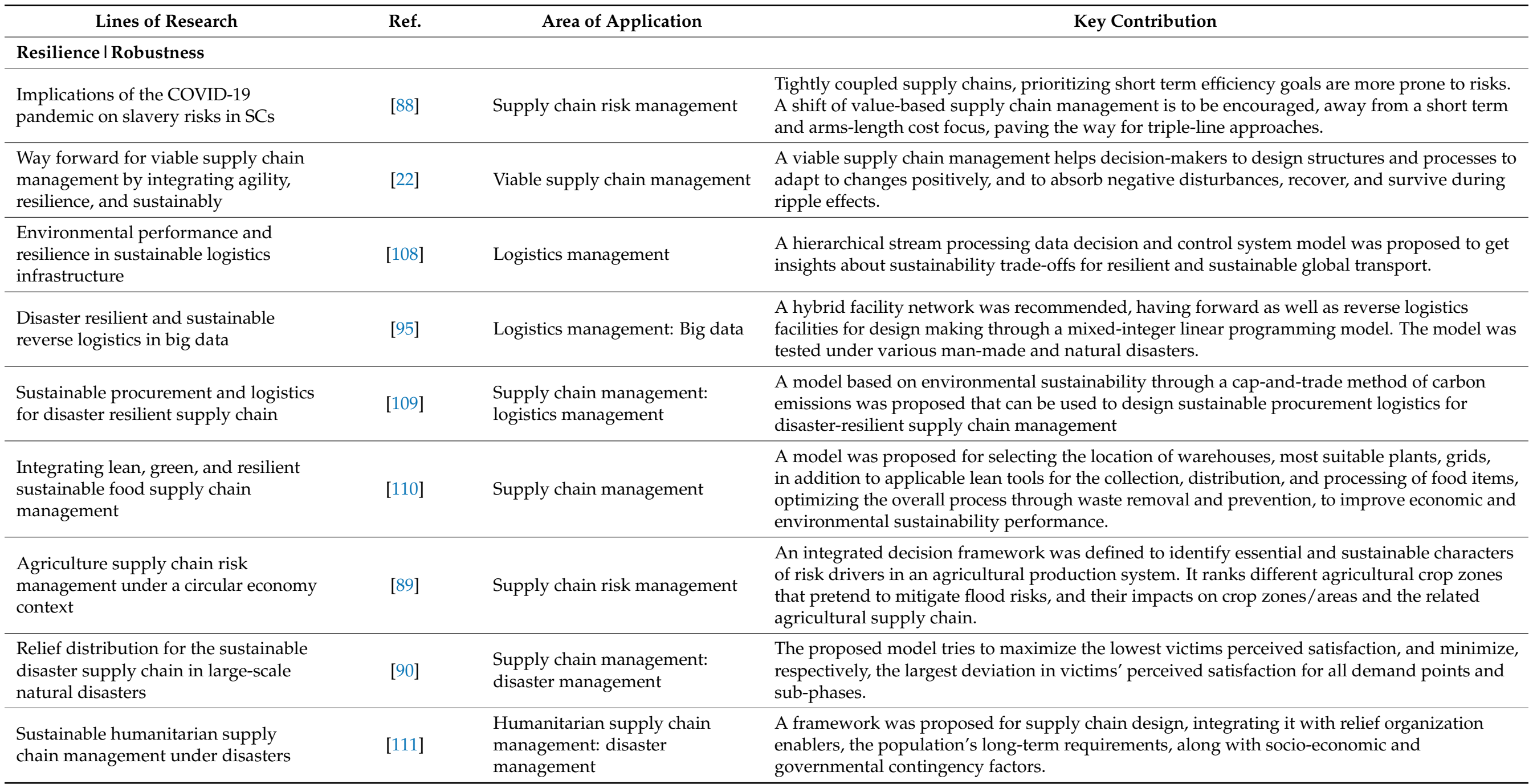


Table 4. Cont.

\begin{tabular}{|c|c|c|c|}
\hline Lines of Research & Ref. & Area of Application & Key Contribution \\
\hline \multicolumn{4}{|l|}{ Resilience | Robustness } \\
\hline $\begin{array}{l}\text { Social entrepreneurship to recover } \\
\text { from disasters }\end{array}$ & [91] & Disaster management & $\begin{array}{l}\text { A conceptual framework was proposed, emphasizing the contributions of social } \\
\text { entrepreneurship in planning, development, delivery, and distribution of services in long-term } \\
\text { recovery humanitarian and development operations }\end{array}$ \\
\hline $\begin{array}{l}\text { The post-disaster challenge for supply } \\
\text { chains }\end{array}$ & [92] & $\begin{array}{l}\text { Supply chain management: } \\
\text { disaster management }\end{array}$ & $\begin{array}{l}\text { The developed model suggested that the poor strategic planning and lack of investment in } \\
\text { ex-ante measures (limited number and capacity of shelters, and smaller number of in-country } \\
\text { warehouses lead to the lack of sustainable relief aid. }\end{array}$ \\
\hline Assessing supply chain resilience & [113] & Supply chain management & $\begin{array}{l}\text { A model based on three categories of indicators was proposed to assess resilience, such as an } \\
\text { organizational resilience in terms of responsiveness, flexibility, and effectiveness, attaining } \\
\text { business resilience (to assess by cash-to-cash, days of inventory, days of receivables, and days of } \\
\text { payables), and labor resilience, based on capabilities for overcoming vulnerable living } \\
\text { conditions. }\end{array}$ \\
\hline $\begin{array}{l}\text { Evaluating impacts of COVID-19 on } \\
\text { supply chains }\end{array}$ & [5] & Supply chain risk management & $\begin{array}{l}\text { It was concluded that the timing of the closing and opening of the facilities at different echelons } \\
\text { might become a major factor that determines the epidemic outbreak's impact on SC } \\
\text { performance, rather than upstream disruption duration or the speed of epidemic propagation }\end{array}$ \\
\hline
\end{tabular}




\subsection{Positive Aspects of COVID-19 on Businesses}

At the start of the pandemic, many businesses largely stopped their operations due to extremely low demand. This led to laying off many employees, dropping a significant market share, and going bankrupted. However, some businesses profited from the situation, and scaled up their services and market share [114]. For instance, the USA's year over year revenue for online businesses rose $68 \%$. Similarly, a $129 \%$ revenue growth was seen in online businesses in USA and Canada. Companies like Facebook and Amazon have revolutionized e-commerce services. Likewise, DoorDash, UberEats, Zoom (online conferencing platform), and Netflix gained a tremendous number of customers and their share prices sky-rocketed [114,115]. Conclusively, the businesses who provide products and services to customers through electronic platforms gained popularity and got an amazing response from the public. However, the businesses totally depending on physical means faced significant challenges [114]. In addition, the pandemic pushed businesses to cut operating costs through work-from-home possibilities. Furthermore, companies adopted electronic-meetings and collaboration systems to gain the best services from geographically dispersed teams in other time zones.

\section{Future Research Avenues}

The outcomes of this research can be used to advance researchers' perspectives on future developments in SC research. Similarly, our results can be of value for decision-makers to decipher the possibilities and barriers in the process of sustainable and viable SC transformations.

This section mainly covers the managerial, social, and theoretical implications of the objective to secure survivability during epidemic outbreaks, as identified from Table 3 and Table 4, and to explicitly formulate "future research avenues in SC under epidemic outbreaks". Through rigorous content analysis and synthesis of the previously available studies, open research questions along with the major literature gaps, as well as an original idea, are identified and recommendations for a future roadmap to deal with the issues generated through ripple effects and disruptions are made for researchers, scholars, practitioners, and other related experts, as shown in Table 5. The research avenues are for experts in modelling and framework developers to roadmap the solution to the various highlighted problems. Mainly, these research gaps are at a system level, process level, organizational level, a societal level, and global level. The major areas to work on are identified to extend development using advanced tools and techniques, which proved to be effective in (Table 3) previous practices. For instance, operations management strategies such as simulation, optimization, and so on. Where the organizational approach is concerned, digitally supported intertwined supply chain networks provide an opportunity to interconnect the processes at the highest integration level, and help to connect to the real customer [24,44].

Furthermore, the co-benefits of this epidemic are not clear yet. Due to the drastic reduction in sales, multiple industrial businesses and global SCs, and coping with the shortages of medical supplies, are forced to build in-house manufacturing capabilities. Whereas additive manufacturing and artificial intelligence technologies are continuously helping SCs to recover from the shock, and continue operations as normal [116-118]. Some of the developments in material science also support in terms of bio-support [119-121].

In Table 5, there are four columns, namely "reference", "literature gap", "open questions and opportunities for future research", and "roadmap approaches". Some of the research opportunities are identified and represented concisely. Therefore, to make the opportunities more clear, explicit and open questions are provided. To address the solution to the questions, some guideline approaches are taken from operations research and management, as shown in Figure 2. In this highly disrupted SC environment, operations research and operations management $(\mathrm{OM})$ is helping practitioners to analyze the constraints, and to take decisions accordingly. For instance, network design and complexity theories, simulation, optimization, and resilience help to set short-term goals for transport, production, and worker movement, while where long-term goals are concerned, the industrial revolution is assisting with digitalization. 
Table 5. Proposed research extension opportunities and agenda for investigating and effectively responding to an epidemic's effects on SCs.

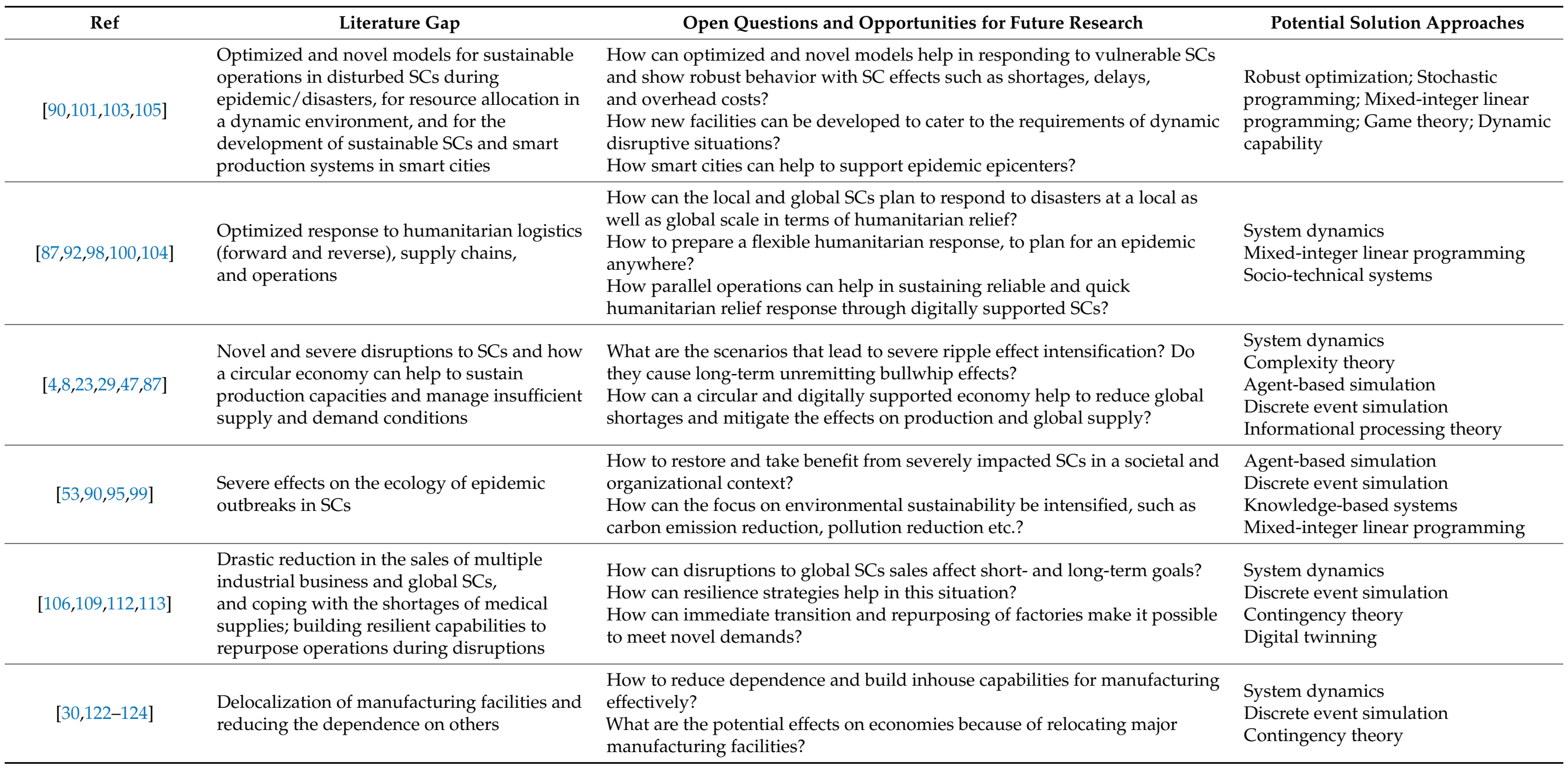


Table 5. Cont.

Ref Literature Gap

Blockchain as an aid to reduce disruption effects through effective information flow

Artificial intelligence and additive

$[22,43,93,96,103,116$ 126-128] manufacturing to support SCs during

epidemic outbreaks
Open Questions and Opportunities for Future Research

How blockchain technologies, such as traceability through visibility and security can help to reduce the shortages?

How can this help in quickly responding to the disruption?

How artificial intelligence can help industries through digital manufacturin

and other assistive technologies in the epoch of epidemics?

How can artificial intelligence help in making responsive models, and by

providing an optimized strategy through heuristics?

How to make an assessment of technological readiness, and roadmap the

transformation journey to combat future disruptions?

How additive manufacturing assistance with artificial intelligence can

repurpose manufacturing demand through digital as well as social media

data analytics?

How can additive manufacturing contribute to meet urgent demand, such as

surgical masks, protective equipment, and so on?

\section{Potential Solution Approaches}

Complexity theory

Reliability theory

Dynamic capabilities

Convex programming

Mixed-integer linear programming

System dynamics

Discrete event simulation

Organizational resilience

Complexity theory

Heuristics

Machine/Deep learning-based models 
In the context of responding to epidemic disruptions, these opportunities and theories give valuable support to SCs. Mathematical optimization, including mixed-integer linear and nonlinear programming, and their solutions through advanced heuristics help in developing optimized plans and networks, for assisting decision-makers in their analytical modeling of the situation. This helps in making optimized decisions on quantitative grounds, planning to avoid shortages, and scheduling for fluctuating demands during pandemics (mask production, sanitizers, ventilators, toilet paper in the case of COVID-19). Similarly, as mentioned in Table 5, simulation is one of the powerful tools which helps to compare incorrect and successful elements in an SC response plan. Furthermore, it helps to make robust plans in response to a pandemic's dynamic status. For instance, agent-based simulation helps to evaluate operations by taking multiple agents into account, especially in the case of COVID-19, where the multiple interactions of stakeholders can be evaluated. COVID-19 is an unmatched, highly contagious, and economically disruptive event for SCs, therefore decision-makers, practitioners, and experts can evaluate the current situation through the approaches mention in Table 5 and Figure 2, and by integrating multiple approaches, such as simulation theory with reliability analysis, and optimization models with a fuzzy based uncertainty environment. They can develop various complex and interconnected scenarios for evaluating shortages of supply and variations of demand, resource allocation problems, and logistic network design, and find an optimized solution at each stage and period of the pandemic.

The framework for SCs to cope with the problems caused by a pandemic is shown in Figure 7, which was extracted from Tables 3-5. It shows the key areas to focus on in this era; as previously the experience of pandemics was quite different. As at earlier times, the advanced technological tools and assistive approaches were not available. However, in this time, with the increase in the extent of the epidemic outbreak, the technology of counterstrategies has also advanced to deal with the problems easily and return to the normal condition. To cover the gap between previous practices in responding to pandemics and in those in this technological era, a framework is suggested which is discussed in different sections.

\subsection{Sustainability/Survivability Preparedness}

To prepare SCs for greater reliability and survival during deeply uncertain environments, first a focus on the preparedness aspect (for survivability) was highlighted by our SLR on the effects of epidemic outbreaks on SCs. On the path of sustainability, these key areas are highlighted more during content analyses, such as cost efficiency, agility, flexibility, resource efficiency, environmental footprint, and reliability. Moreover, there are not only opportunities in the domain of mathematical optimization and simulation, but also with other approaches, for example queuing theory, system dynamics, effective scheduling and forecasting, and knowledge-based systems can be explored $[39,78]$. This indicates that decision-makers should employ a diverse integrated approach to improving SC survivability and sustainability perspective $[101,103,105]$. Moreover, simulation-based approaches are commonly used [129] to evaluate different decisions during an epidemic for better response to SC operation disruptions [5,23,130,131]. Simulation is used as a predictive tool to test decisions, massive disruptions, and performance capacities. In addition to this, consideration of SC ecosystems, viability analysis, intertwined network analysis, and humanitarian logistics also play a key role in SC sustainability. However, inter-domain areas overlapping with resilience and robustness include risk mitigation learning, pre-allocation of resources, emergency distribution planning, and product diversification and substitution. Our study sheds more light on the management and allocation of resources, as evident from previous approaches mentioned in Table 3.

Additionally, sustainability itself, as a focus of our SLR is discussed through considering SC ecosystems, and the viability of the system, operations, and network; as well as novel and severe disruptions to SCs and how a circular economy can help to sustain production capacities, and deal with insufficient supply and demand conditions, to ensure 
short-term and long-term SC sustainability and survivability $[8,87]$. Moreover, the feedback in SC ecosystems, both positive (cycle of natural resources) or negative (cycle of emissions as a contributor to climate change), and the interactions of SC stakeholders, such as society, organization was also considered. Similarly, workforce development, technological innovations are positive interactions, whereas strikes (SC disruptions and organization-based resilience level), global disruptions (pandemics or epidemic outbreaks causing SC disruptions at survivability level) are negative interactions. Attempts to manage these negative implications are made through a focus on the overlap of sustainability/survivability with industry 4.0/digitalization. "Disruption recovery learning", "disruption pattern recognition", and "disruption identification" in highly interconnected digitally assisted SCs can bring integrity through intertwined networks. This requires incorporating all the stakeholder at all levels, such as society, organizations, system, and processes [24]. Moreover, humanitarian logistics and crises regarding SC sustainability are also vital areas to explore further in the field $[125,132,133]$.

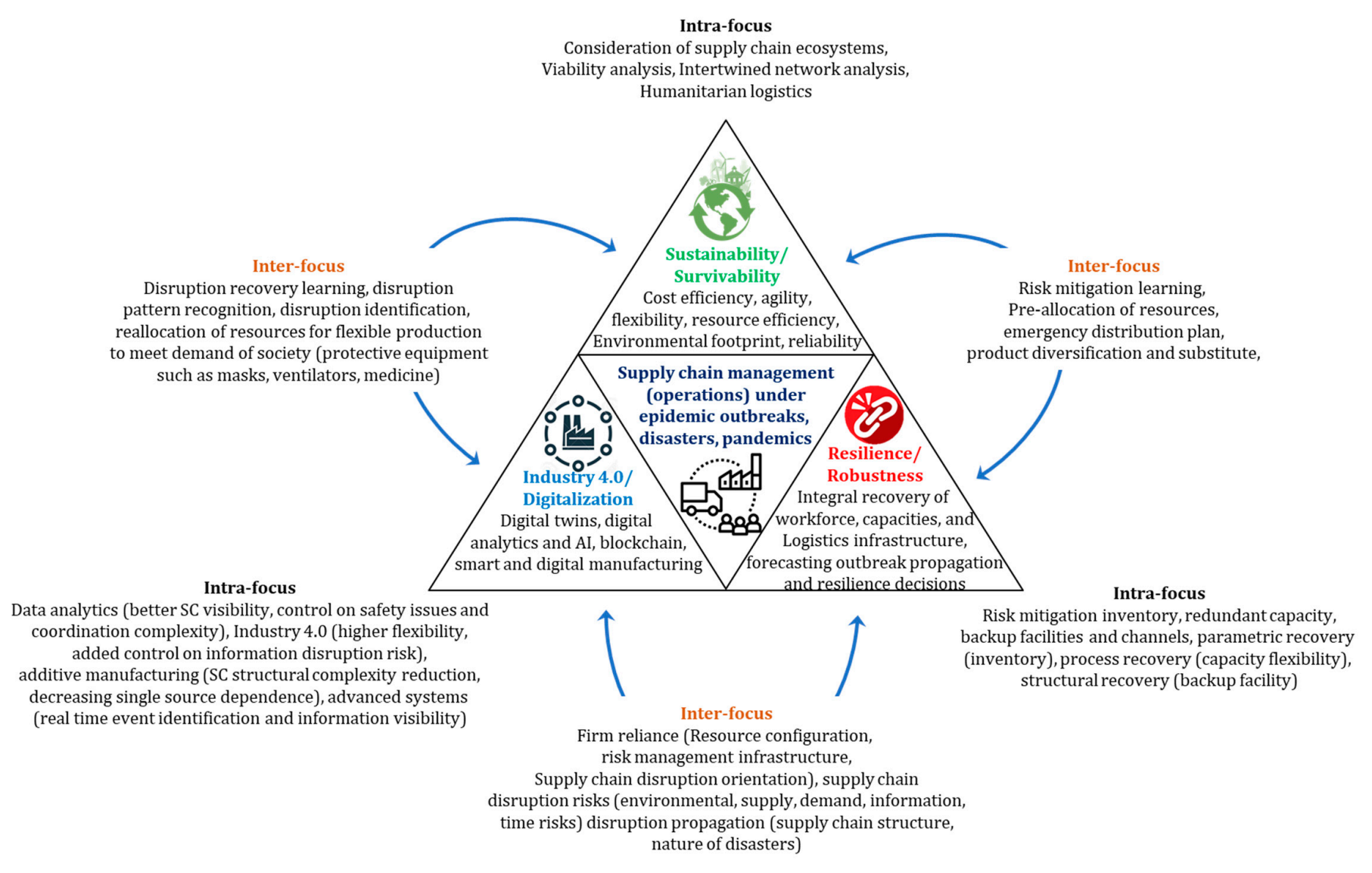

Figure 7. Framework for the readiness of SCs to combat pandemics.

\subsection{Digital/Industry 4.0 Vigilance}

There is an urgent need to evaluate the current technological readiness level for industry 4.0 transformation to firmly combat COVID-19-like future disruptions. Earlier, cutting-edge technologies such as blockchain, additive manufacturing, and artificial intelligence (AI) were not available to industries, but in this epoch, these technologies provide high-end traceability, robustness, and resilience to SCs. First, the analysis of an epidemic outbreak's effects on SCs can be carried out, followed by an assessment of the current technology level [134], and lastly a framework for developed, under-developed, and developing countries (as dynamics are different in every community) to roadmap the transformation journey. These technologies (artificial intelligence, Industry 4.0) could play a crucial role 
in SC resilience and robustness against ripple effects [44,135]. In terms of visibility and digital manufacturing networks, we can foresee a viable option for assuring workability during a crisis and the coordination of recovery from future pandemics [125,136]. "Digital twins", "digital analytics and $\mathrm{AI}^{\prime}$, and "smart and digital manufacturing" are remarkably good ways forward, and are sure to support SCs. Whereas the overlap of this focus with resilience and robustness of SCs was also identified by our SLR. The collaboration of "Industry 4.0/digitalization" with "resilience/robustness" offers a way forward through firm reliance, in terms of resource configuration and risk management infrastructure $[44,137,138]$.

\subsection{Resilience/Robustness Readiness}

The next focus on SCs is their readiness to respond to the impacts of remarkably high and unexplored ripple effects. Companies and economies are facing a great depression due to the COVID-19 pandemic [139-141]. This is an important aspect of understanding the implications of ripple effects and pandemic stress on SCs, and the possibilities of collapse due to disease and disruption propagation through networks. Though multiple aspects of ripple effects have been simulated and studied in various dimensions they deserve to be explored more $[4,131,137]$. The journey for resilience and robustness of SCs starts from evaluating ripple effects, then the adaptation of new terms, leading towards the recovery phase. Several tensions in SCs were reported from previous pandemics, as mentioned in Table 3, and several operation management approaches have been used to address resource allocation. Practitioners, decision makers, managers, and experts continuously try to monitor SCs performance, to rigorously evaluate the disruptions, and to make a recovery plan covering all aspects and leaving nothing unexamined. To ensure the recovery plan is successful certain key roles need to be addressed, such as "risk mitigation inventory", "redundant capacity", and "backup facilities and channels". These are the significant areas which are needed to make SCs robust, as well as resilient against such pandemics.

To summarize, SCs must operate with the assistance of operations management approaches and the aspects mentioned in Figure 7; from a resilience and survivability perspective, to avoid supply shortages, and delivering an optimized, responsive, and dynamic decision support model for different stages of disaster, pandemics, and outbreaks, through taking aid from simulations, mathematical optimization, and network and complexity theories.

\subsection{A Conclusive Insight}

This research study covers the main aspects by classifying different epidemic outbreaks and SC resilience objectives addressed from the view of local as well as global pandemics. The overall insight of our SLR analysis orientates the traditional SCs towards risk, resilience, and sustainable understanding, to tackle severe, destructive, unmatched global disruptions and disasters. Hence, multiple approaches were found significant to address issues during a pandemic $[106,125,138]$. Therefore, there is always a continuous need, as per the understanding from the analysis of a SLR, to explore existing approaches [134], extend them, or propose new $[23,107]$ ones, to deal with new challenges, and we urge experts to explore the areas mentioned in Table 5 with novel approaches or hybrid techniques.

Initially, the categorization of major epidemic outbreaks which disturbed SCs significantly was carried out. The potential research objectives which were addressed are displayed in Table 3, and the possible solution methodologies were extracted to make a roadmap for the journey of the COVID-19 pandemic. Therefore, different SC survivability aspects were explored from previous practices in the context of pandemic disruptions, and making resilience a goal for the whole SC network, system, organization, and process, as reported from Table 3. To make SCs ready for future disruptions certain critical components of SCs were extracted, such as resilience and robustness, sustainability and survivability, digitalization, and industry 4.0. All these components play a crucial role during pandemics and are interrelated, such as in the aspects of readiness, vigilance, responsiveness, and preparedness for effective recovery from the disruptions caused by epidemics. 
Various governments have been establishing uncommon collaborative activities with manufacturing firms and specific suppliers for the reconfiguration, adaption, and rampingup of production to provide medical facilities to ensure resilience and flexibility in systems [127,128,142]; this may partially be achieved through digitalization $[128,142-149]$. Moreover, numerous global societies need to tackle the mismatch between supply and demand in distinct ways, providing social distancing and other cautionary measures [27]. In addition to this, the use of collaborative robots for reconfiguration of existing production setups can be foreseen to enhance the flexibility of a system; for instance, adapting automotive industry for the production of ventilators [127,142]. This could be a future research and development direction to deal with pandemics and large-scale disasters [27]. An exponential growth in research and development in this direction could be seen in the near future [27].

\section{Practical Implications for Researchers and Practitioners}

This comprehensive survey on epidemic outbreaks discussed outbreak's categorization regarding developments in the efficiency improvement of SCs, insights into SC sustainability, viability, and digital technology, and focused on pandemics, research opportunities to combat future pandemics, and a unanimous framework to improve reliability. These contributions will help decision makers, practitioners, policy makers, and business tycoons in strategizing their supply chain operations with resilient strategies.

Through content analysis of our SLR, a framework was deduced to emphasize the robustness and sustainability aspect through Industry 4.0 and operations management approaches to increase viability and SC survivability in the notable disruptions caused by epidemics. The important aspect was to introduce and improve the resilience performance of SCs [149-152] through buffer demands, redundancy systems, and overlapped approaches of digitalization [143-149], especially through characterizing changeability of systems across value chains $[145,152]$, using augmented/virtual reality solutions in support of intelligent manufacturing, Industry 4.0, industrial digitalization and futureproofing through-life engineering service systems [143,146-149,152], using 20+ Industry 4.0 technologies, particularly in SMEs [147], and traceability [106,138]. Physical, as well as digital SCs, support various interactions for examining the effects of the epidemic outbreak as well [44]. Another important aspect concerning processes is the flexibility in product development and management, as identified by our SLR. During pandemics, fluctuations in demand of normally produced goods, and increased demand of specific items required to control and manage epidemic outbreaks, entail repurposing and redesigning manufacturing setups $[127,151]$. Therefore, the interplay between process flexibility and product management needs to ensure the flow of products, without any shortages and disruptions, which can be met through process redundancy and safeguarding SC in terms of resilience [64,107]. Furthermore, adequate robustness and control over SC disruptions and resilience is another challenge for organizations.

The unmatched disruption of COVID-19 has also put a strain on system dynamics, urging the need for novel policies related to inventory, manufacturing, and transportation, and integrated with resilience aims [136]. The recovery from disturbances highly depends upon the roadmap of resilience and survivability $[88,144]$. Short-term and long-term goals include the movement of labor, and ensuring transport and production to avoid any type of shortages. This needs the interconnection between resources such as production flexibility, human resources, transportation constraints, and regional policies to manage the disruptions effectively. The revival course can be fast-tracked through the effective use of modern technologies and alternative sources, aided by the goal of production flexibility. References $[127,142]$ provide a framework for reconfiguring industries to streamline their production systems to produce supplies that are lacking (ventilators), to nullify an epidemic's effect on SCs to a considerable extent. Researchers and practitioners can be helped by these research directions, which provide opportunities to extend investigations on supply chains operations, and to develop strategic solutions to combat tough situations. 


\section{Conclusions}

Pandemics and epidemic outbreaks cause chaotic situations in SCs around the globe, and can lead towards serious survivability challenges for many SCs. Therefore, in this research study, we expressed the impacts of previous epidemic outbreaks on SCs through a unique blend of articles to identify research objectives, methodological approaches, and the implications for SCs. Moreover, the study presented a systematic analysis of the sustainability and viability perspective of SCs, by using a structured literature review and the extraction of future research avenues, which have not been comprehensively focused before. This study found that the interaction between SCs and epidemic outbreaks has been explored in terms of effective resource allocation, disease management, aid distribution, and transportation network optimization, through operations management techniques, such as optimization, complexity theories, and so on. Moreover, several epidemic models have also been used in a similar context, as reported in the nominated pandemics in Table 3. In addition to this, multiple aspects for ensuring the sustainability of SCs in tough conditions were reported, to guide future research opportunities, considering modern approaches and technologies. In this respect, COVID-19 has had destructive effects on global SCs, causing full, partial, or smart shutdowns of numerous manufacturing industries [34]. Whereas refs. [5,47] tried to provide an insight into its impacts on SCs. However, the research on the topic is not yet mature, offering continuing opportunities for evaluating the consequences. Therefore, this research study identified literature gaps and research avenues related to the optimization of sustainable operations during epidemic outbreaks, the response to humanitarian logistics and operations, how a circular economy helps to sustain the production capacities, the severe effects on ecologies, and artificial intelligence and additive manufacturing.

Specifically, we propose a framework for the readiness of SCs to combat epidemic outbreaks, disasters, and pandemics, such as COVID-19. The framework covers the classifications and categorization of three major areas, i.e., resilience and robustness, sustainability and survivability, and digitalization and Industry 4.0. One of the novel aspects of this study is that it has shown the interplay between SCs in pandemics and Industry 4.0, specifically in the context of long-term sustainability and survivability during epidemic outbreaks. This study has only explored research articles related to novel theoretical and practical tensions, including 30-40 concerning the effects of epidemic outbreaks and SCs, precisely 32 on the context of survivability and sustainability of SCs during large scale disasters (pandemics), and 25-35 supporting and explicitly discussing literature gaps and research opportunities. The rest of the articles were for the endorsement of the significance of this research study. Considering these limitations, we have proposed research directions, including promising areas to be explored relating to epidemic outbreaks. In the future, the databases, search domain, keyword themes, and interesting protocols can be explored for comparative studies on COVID-19 and other epidemic outbreaks. Moreover, one encouraging direction of research is to assess industries' readiness level for Industry 4.0 and digitalization, and to propose a unanimous framework for implementation of these technologies. Since the conditions vary significantly between different manufacturing hubs and countries, therefore, individual assessments and roadmaps for global SCs will be appreciated. Moreover, the concept of the viability of SCs through these promising areas can integrate the resilience, sustainability, survivability, and robustness of pandemicaffected SCs $[24,125]$. In addition to this, artificial intelligence and integrated operations management methods can also help to successfully gauge ripple effects [4,117], and reveal the economic, ecological, and social implications during and after the COVID-19 pandemic, and make a considerable impact on future epidemic outbreaks.

Author Contributions: Conceptualization, M.U.F.; methodology, M.U.F. and M.S.H.; software, M.S.H.; validation, M.U.F. and M.S.H.; formal analysis, M.U.F., A.H., T.M. and M.S.H.; investigation, M.U.F. and M.S.H.; resources, T.M.; data curation, M.U.F. and M.S.H.; writing-original draft preparation, M.U.F.; writing-review and editing, M.U.F., A.H. and T.M.; visualization, M.S.H.; super- 
vision, A.H., M.S.H. and M.U.F.; project administration, A.H.; funding acquisition, T.M. All authors have read and agreed to the published version of the manuscript.

Funding: This research received no external funding. The Article Processing Charges (1900 CHF) were waived by the MDPI Sustainability journal.

Institutional Review Board Statement: Not applicable.

Informed Consent Statement: Not applicable.

Data Availability Statement: The data that support the findings of this study are available on request from the corresponding author [M.U.F.].

Acknowledgments: Authors would like to acknowledge the constructive feedback from the Industry 4.0 research initiative of Department of Industrial and Manufacturing Engineering, University of Engineering and Technology Lahore in collaboration with Korea Advanced Institute of Science and Technology (KAIST) and the Industrial Systems of the Future programme of the University of Cambridge.

Conflicts of Interest: The authors declare no conflict of interest among themselves and with the material presented.

\section{References}

1. Hofmann, H.; Busse, C.; Bode, C.; Henke, M. Sustainability-related supply chain risks: Conceptualization and management. Bus. Strategy Environ. 2014, 23, 160-172. [CrossRef]

2. Yaghlane, A.B.; Azaiez, M.N. Systems under attack-survivability rather than reliability: Concept, results, and applications. Eur. J. Oper. Res. 2017, 258, 1156-1164. [CrossRef]

3. Shareef, M.A.; Dwivedi, Y.K.; Mahmud, R.; Wright, A.; Rahman, M.M.; Kizgin, H.; Rana, N.P. Disaster management in Bangladesh: Developing an effective emergency supply chain network. Ann. Oper. Res. 2019, 283, 1463-1487. [CrossRef]

4. Yu, K.D.S.; Aviso, K.B. Modelling the economic impact and ripple effects of disease outbreaks. Process Integr. Optim. Sustain. 2020, 4, 183-186. [CrossRef]

5. Ivanov, D. Predicting the impacts of epidemic outbreaks on global supply chains: A simulation-based analysis on the coronavirus outbreak (COVID-19/SARS-CoV-2) case. Transp. Res. Part E Logist. Transp. Rev. 2020, 136, 101922. [CrossRef]

6. Mobula, L.M.; Samaha, H.; Yao, M.; Gueye, A.S.; Diallo, B.; Umutoni, C.; Anoko, J.; Lokonga, J.-P.; Minikulu, L.; Mossoko, M. Recommendations for the COVID-19 Response at the National Level Based on Lessons Learned from the Ebola Virus Disease Outbreak in the Democratic Republic of the Congo. Am. J. Trop. Med. Hyg. 2020, 103, 12-17. [CrossRef]

7. Olu, O.O.; Lako, R.; Wamala, J.F.; Ramadan, P.O.; Ryan, C.; Udenweze, I.; Berta, K.; Guyo, A.G.; Sokemawu, A.; Tukuru, M. What did we learn from preparing for cross-border transmission of Ebola virus disease into a complex humanitarian setting-The Republic of South Sudan? Infect. Dis. Poverty 2020, 9, 1-7. [CrossRef]

8. Fernandes, N. Economic Effects of Coronavirus Outbreak (COVID-19) on the World Economy. Available online: https://papers. ssrn.com/sol3 / papers.cfm?abstract_id=3557504 (accessed on 23 February 2021).

9. Habib, M.S.; Sarkar, B.; Tayyab, M.; Saleem, M.W.; Hussain, A.; Ullah, M.; Omair, M.; Iqbal, M.W. Large-scale disaster waste management under uncertain environment. J. Clean. Prod. 2019, 212, 200-222. [CrossRef]

10. WHO | Disasters and Emergencies. Available online: http://www.who.int/surgery/challenges/esc_disasters_emergencies/en/ (accessed on 5 July 2020).

11. Mari, S.I.; Lee, Y.H.; Memon, M.S. Sustainable and resilient supply chain network design under disruption risks. Sustainability 2014, 6, 6666-6686. [CrossRef]

12. Smith, K.F.; Goldberg, M.; Rosenthal, S.; Carlson, L.; Chen, J.; Chen, C.; Ramachandran, S. Global rise in human infectious disease outbreaks. J. R. Soc. Interface 2014, 11, 20140950. [CrossRef]

13. Sarkis, J.; Cohen, M.J.; Dewick, P.; Schröder, P. A brave new world: Lessons from the COVID-19 pandemic for transitioning to sustainable supply and production. Resour. Conserv. Recycl. 2020, 159, 104894. [CrossRef]

14. WHO Coronavirus Disease (COVID-19) Outbreak Situation. Available online: https://www.who.int/emergencies/diseases/ novel-coronavirus-2019 (accessed on 24 June 2020).

15. WHO Director-General's Opening Remarks at the Media Briefing on COVID-19-11 March 2020. Available online: https:/ /www. who.int/dg/speeches/detail/who-director-general-s-opening-remarks-at-the-media-briefing-on-covid-19---11-march-2020 (accessed on 24 June 2020).

16. Cheema-Fox, A.; LaPerla, B.R.; Serafeim, G.; Wang, H.S. Corporate Resilience and Response during COVID-19. Available online: https:/ / papers.ssrn.com/sol3/papers.cfm?abstract_id=3578167 (accessed on 23 February 2021).

17. Gehrie, E.A.; Frank, S.M.; Goobie, S.M. Balancing supply and demand for blood during the COVID-19 pandemic. Anesthesiology 2020, 133, 16-18. [CrossRef] 
18. Govindan, K.; Mina, H.; Alavi, B. A decision support system for demand management in healthcare supply chains considering the epidemic outbreaks: A case study of coronavirus disease 2019 (COVID-19). Transp. Res. Part E Logist. Transp. Rev. 2020, 138, 101967. [CrossRef]

19. Hobbs, J.E. Food supply chains during the COVID-19 pandemic. Can. J. Agric. Econ. Rev. Can. Agroecon. 2020, 68, 171-176. [CrossRef]

20. International Journal of Production Research IJPR SI: Production of Healthcare under Epidemic Outbreaks. Available online: https:/ / www.journalconferencejob.com/production-healthcare-epidemic (accessed on 24 June 2020).

21. International Journal of Production Research IJPR SI: Viability of Supply Networks \& Ecosystems: Lessons Learned from COVID19. Available online: https:/ / www.journalconferencejob.com/viability-supply-networks-ecosystem (accessed on 24 June 2020).

22. Ivanov, D. Viable supply chain model: Integrating agility, resilience and sustainability perspectives-Lessons from and thinking beyond the COVID-19 pandemic. Ann. Oper. Res. 2020, 1-21. [CrossRef]

23. Ivanov, D.; Das, A. Coronavirus (COVID-19/SARS-CoV-2) and supply chain resilience: A research note. Int. J. Integr. Supply Manag. 2020, 13, 90-102. [CrossRef]

24. Ivanov, D.; Dolgui, A. Viability of intertwined supply networks: Extending the supply chain resilience angles towards survivability. A position paper motivated by COVID-19 outbreak. Int. J. Prod. Res. 2020, 58, 2904-2915. [CrossRef]

25. Journal of Operations Management Special Issue of the Journal of Operations Management-The Effects of COVID-19 on Global Supply Chains: Responsiveness, Resilience, and Restoration (3Rs). Available online: https:/ / onlinelibrary.wiley.com/pb-assets / assets /18731317/JOMCFP-COVID-19andglobalsupplychains-1585601180383.pdf (accessed on 24 June 2020).

26. Park, C.-Y.; Kim, K.; Roth, S. Global Shortage of Personal Protective Equipment Amid COVID-19: Supply Chains, Bottlenecks, and Policy Implications; Asian Development Bank: Mandaluyong, Philippines, 2020.

27. Medel, K.; Kousar, R.; Masood, T. A Collaboration-Resilience Framework for Disaster Management Supply Networks: A Case Study of the Philippines. J. Humanit. Logist. Supply Chain Manag. 2020, 10, 509-553. [CrossRef]

28. Masood, T.; So, E.; McFarlane, D. Disaster Management Operations-Big Data Analytics to Resilient Supply Networks. Available online: http:/ / euroma2017.eiasm.org/userfiles/HKJGLML_GDFJMK_AW7YG3VT.pdf (accessed on 24 February 2021).

29. Business Insider Coronavirus Business \& Economy Impact News I Business Insider. Available online: https://www. businessinsider.com/coronavirus-business-impact (accessed on 25 June 2020).

30. Forbes the COVID-19 Problems That will Force Manufacturing to Innovate. Available online: https://www.forbes.com/sites/ annashedletsky/2020/05/05/the-covid-19-problems-that-will-force-manufacturing-to-innovate/\#7fd49c9230d0 (accessed on 25 June 2020).

31. Fortune How Global 500 Companies are Responding to COVID-19. Available online: https://fortune.com/2020/04/13/global500-companies-coronavirus-response-covid-19-pandemic/ (accessed on 25 June 2020).

32. Harvard Business Review How to Manage Coronavirus Layoffs with Compassion. Available online: https://hbr.org/2020/04/ how-to-manage-coronavirus-layoffs-with-compassion?ab=hero-main-text (accessed on 25 June 2020).

33. Alicke, K.; Azcue, X.; Barriball, E. Supply-Chain Recovery in Coronavirus Times-Plan for Now and the Future. 2020. Available online: https:/ / www.mckinsey.com/business-functions/operations/our-insights/supply-chain-recovery-in-coronavirus-timesplan-for-now-and-the-future (accessed on 25 June 2020).

34. Fortune $94 \%$ of the Fortune 1000 are Seeing Coronavirus Supply Chain Disruptions. Available online: https:/ / fortune.com/2020 /02/21/fortune-1000-coronavirus-china-supply-chain-impact/ (accessed on 2 July 2020).

35. Agyepong, L.A. A systems view and lessons from the ongoing Ebola Virus Disease (EVD) outbreak in West Africa. Ghana Med. J. 2014, 48, 168-172. [CrossRef] [PubMed]

36. Scarpino, S.V.; Petri, G. On the predictability of infectious disease outbreaks. Nat. Commun. 2019, 10, 898. [CrossRef]

37. Anparasan, A.A.; Lejeune, M.A. Data laboratory for supply chain response models during epidemic outbreaks. Ann. Oper. Res. 2018, 270, 53-64. [CrossRef]

38. Preciado, V.M.; Zargham, M.; Enyioha, C.; Jadbabaie, A.; Pappas, G. Optimal vaccine allocation to control epidemic outbreaks in arbitrary networks. In Proceedings of the 52nd IEEE Conference on Decision and Control, Firenze, Italy, 10-13 December 2013; pp. 7486-7491.

39. Dasaklis, T.K.; Pappis, C.P.; Rachaniotis, N.P. Epidemics control and logistics operations: A review. Int. J. Prod. Econ. 2012, 139, 393-410. [CrossRef]

40. Duijzer, L.E.; van Jaarsveld, W.; Dekker, R. Literature review: The vaccine supply chain. Eur. J. Oper. Res. 2018, 268, 174-192. [CrossRef]

41. Kumar, S.; Havey, T. Before and after disaster strikes: A relief supply chain decision support framework. Int. J. Prod. Econ. 2013, 145, 613-629. [CrossRef]

42. Pastor-Satorras, R.; Castellano, C.; Van Mieghem, P.; Vespignani, A. Epidemic processes in complex networks. Rev. Mod. Phys. 2015, 87, 925. [CrossRef]

43. Dolgui, A.; Ivanov, D.; Sokolov, B. Reconfigurable supply chain: The X-network. Int. J. Prod. Res. 2020, 58, 4138-4163. [CrossRef]

44. Ivanov, D.; Dolgui, A. A digital supply chain twin for managing the disruption risks and resilience in the era of Industry 4.0. Prod. Plan. Control 2020, 1-14. [CrossRef] 
45. Broekhuizen, T.L.J.; Broekhuis, M.; Gijsenberg, M.J.; Wieringa, J.E. Introduction to the Special Issue—Digital Business Models: A Multi-Disciplinary and Multi-Stakeholder Perspective; Elsevier: Amsterdam, The Netherlands, 2020.

46. Culot, G.; Nassimbeni, G.; Orzes, G.; Sartor, M. Behind the definition of industry 4.0: Analysis and open questions. Int. J. Prod. Econ. 2020, 226, 107617. [CrossRef]

47. Queiroz, M.M.; Ivanov, D.; Dolgui, A.; Wamba, S.F. Impacts of epidemic outbreaks on supply chains: Mapping a research agenda amid the COVID-19 pandemic through a structured literature review. Ann. Oper. Res. 2020, 1-38. [CrossRef]

48. WEF. The Ongoing Impact of COVID-19 on Global Supply Chains I World Economic Forum. Available online: https://www. weforum.org/agenda/2020/06/ongoing-impact-covid-19-global-supply-chains/ (accessed on 13 July 2020).

49. Durach, C.F.; Kembro, J.; Wieland, A. A new paradigm for systematic literature reviews in supply chain management. J. Supply Chain Manag. 2017, 53, 67-85. [CrossRef]

50. Habib, M.S.; Lee, Y.H.; Memon, M.S. Mathematical models in humanitarian supply chain management: A systematic literature review. Math. Probl. Eng. 2016, 3212095. [CrossRef]

51. Tachizawa, E.M.; Wong, C.Y. Towards a theory of multi-tier sustainable supply chains: A systematic literature review. Supply Chain Manag. Int. J. 2014, 19, 643-663. [CrossRef]

52. Wilding, R.; Wagner, B.; Colicchia, C.; Strozzi, F. Supply chain risk management: A new methodology for a systematic literature review. Supply Chain Manag. Int. J. 2012.

53. de Oliveira, F.N.; Leiras, A.; Ceryno, P. Environmental risk management in supply chains: A taxonomy, a framework and future research avenues. J. Clean. Prod. 2019, 232, 1257-1271. [CrossRef]

54. de Campos, E.A.R.; de Paula, I.C.; Pagani, R.N.; Guarnieri, P. Reverse logistics for the end-of-life and end-of-use products in the pharmaceutical industry: A systematic literature review. Supply Chain Manag. Int. J. 2017, 22, 375-392. [CrossRef]

55. van Eck, N.J.; Waltman, L. How to normalize cooccurrence data? An analysis of some well-known similarity measures. J. Am. Soc. Inf. Sci. Technol. 2009, 60, 1635-1651.

56. Rachaniotis, N.P.; Dasaklis, T.K.; Pappis, C.P. A deterministic resource scheduling model in epidemic control: A case study. Eur. J. Oper. Res. 2012, 216, 225-231. [CrossRef]

57. Liu, M.; Zhang, D. A dynamic logistics model for medical resources allocation in an epidemic control with demand forecast updating. J. Oper. Res. Soc. 2016, 67, 841-852. [CrossRef]

58. Mamani, H.; Chick, S.E.; Simchi-Levi, D. A game-theoretic model of international influenza vaccination coordination. Manag. Sci. 2013, 59, 1650-1670. [CrossRef]

59. Majić, Z.; Jukić, I.; Pavlin, S. Air transport and logistics in pandemic outbreak of influenza A (H1N1) virus. Promet-Traffic Transp. 2009, 21, 441-450. [CrossRef]

60. Savachkin, A.; Uribe, A. Dynamic redistribution of mitigation resources during influenza pandemics. Socio-Econ. Plan. Sci. 2012, 46, 33-45. [CrossRef]

61. Liu, M.; Xu, X.; Cao, J.; Zhang, D. Integrated planning for public health emergencies: A modified model for controlling H1N1 pandemic. J. Oper. Res. Soc. 2020, 71, 748-761. [CrossRef]

62. Khokhar, S.G.; Min, Q.; Su, C. Bird flu (H7N9) outbreak and its implications on the supply chain of poultry meat in China. J. Appl. Poult. Res. 2015, 24, 215-221. [CrossRef]

63. Hessel, L.; European Vaccine Manufacturers (EVM) Influenza Working Group. Pandemic influenza vaccines: Meeting the supply, distribution and deployment challenges. Influenza Respir. Viruses 2009, 3, 165-170. [CrossRef] [PubMed]

64. Orenstein, W.A.; Schaffner, W. Lessons learned: Role of influenza vaccine production, distribution, supply, and demand-what it means for the provider. Am. J. Med. 2008, 121, S22-S27. [CrossRef] [PubMed]

65. Chick, S.E.; Mamani, H.; Simchi-Levi, D. Supply chain coordination and influenza vaccination. Oper. Res. 2008, 56, 1493-1506. [CrossRef]

66. Cruz, M.A.; Hawk, N.M.; Poulet, C.; Rovira, J.; Rouse, E.N. Public health incident management: Logistical and operational aspects of the 2009 initial outbreak of H1N1 influenza in Mexico. J. Emerg. Manag. 2015, 13, 71-77. [CrossRef] [PubMed]

67. Ekici, A.; Keskinocak, P.; Swann, J.L. Modeling influenza pandemic and planning food distribution. Manuf. Serv. Oper. Manag. 2014, 16, 11-27. [CrossRef]

68. Sun, L.; DePuy, G.W.; Evans, G.W. Multi-objective optimization models for patient allocation during a pandemic influenza outbreak. Comput. Oper. Res. 2014, 51, 350-359. [CrossRef]

69. Enayati, S.; Özaltın, O.Y. Optimal influenza vaccine distribution with equity. Eur. J. Oper. Res. 2020, 283, 714-725. [CrossRef]

70. Büyüktahtakın, İ.E.; des-Bordes, E.; Kıbış, E.Y. A new epidemics-logistics model: Insights into controlling the Ebola virus disease in West Africa. Eur. J. Oper. Res. 2018, 265, 1046-1063. [CrossRef]

71. Bogoch, I.I.; Creatore, M.I.; Cetron, M.S.; Brownstein, J.S.; Pesik, N.; Miniota, J.; Tam, T.; Hu, W.; Nicolucci, A.; Ahmed, S. Assessment of the potential for international dissemination of Ebola virus via commercial air travel during the 2014 west African outbreak. Lancet 2015, 385, 29-35. [CrossRef]

72. Long, E.F.; Nohdurft, E.; Spinler, S. Spatial resource allocation for emerging epidemics: A comparison of greedy, myopic, and dynamic policies. Manuf. Serv. Oper. Manag. 2018, 20, 181-198. [CrossRef]

73. Anparasan, A.; Lejeune, M. Resource deployment and donation allocation for epidemic outbreaks. Ann. Oper. Res. 2019, 283, 9-32. [CrossRef] 
74. Muggy, L.; Stamm, J.L.H. Decentralized beneficiary behavior in humanitarian supply chains: Models, performance bounds, and coordination mechanisms. Ann. Oper. Res. 2020, 284, 333-365. [CrossRef]

75. Anparasan, A.; Lejeune, M. Analyzing the response to epidemics: Concept of evidence-based Haddon matrix. J. Humanit. Logist. Supply Chain Manag. 2017, 7, 266-283. [CrossRef]

76. Parvin, H.; Beygi, S.; Helm, J.E.; Larson, P.S.; Van Oyen, M.P. Distribution of medication considering information, transshipment, and clustering: Malaria in Malawi. Prod. Oper. Manag. 2018, 27, 774-797. [CrossRef]

77. Dasaklis, T.K.; Rachaniotis, N.; Pappis, C. Emergency supply chain management for controlling a smallpox outbreak: The case for regional mass vaccination. Int. J. Syst. Sci. Oper. Logist. 2017, 4, 27-40. [CrossRef]

78. Paul, S.; Venkateswaran, J. Designing robust policies under deep uncertainty for mitigating epidemics. Comput. Ind. Eng. 2020, 140, 106221. [CrossRef]

79. Wang, H.; Wang, X.; Zeng, A.Z. Optimal material distribution decisions based on epidemic diffusion rule and stochastic latent period for emergency rescue. Int. J. Math. Oper. Res. 2009, 1, 76-96. [CrossRef]

80. Einav, S.; Hick, J.L.; Hanfling, D.; Erstad, B.L.; Toner, E.S.; Branson, R.D.; Kanter, R.K.; Kissoon, N.; Dichter, J.R.; Devereaux, A.V. Surge capacity logistics: Care of the critically ill and injured during pandemics and disasters: CHEST consensus statement. Chest 2014, 146, e17S-e43S. [CrossRef] [PubMed]

81. Bóta, A.; Gardner, L.M.; Khani, A. Identifying critical components of a public transit system for outbreak control. Netw. Spat. Econ. 2017, 17, 1137-1159. [CrossRef]

82. Tao, Y.; Shea, K.; Ferrari, M. Logistical constraints lead to an intermediate optimum in outbreak response vaccination. PLoS Comput. Boil. 2018, 14, e1006161. [CrossRef]

83. Shamsi G., N.; Ali Torabi, S.; Shakouri G., H. An option contract for vaccine procurement using the SIR epidemic model. Eur. J. Oper. Res. 2018, 267, 1122-1140. [CrossRef]

84. Habib, M.S.; Asghar, O.; Hussain, A.; Imran, M.; Mughal, M.P.; Sarkar, B. A robust possibilistic programming approach toward animal fat-based biodiesel supply chain network design under uncertain environment. J. Clean. Prod. 2021, 278, 122403. [CrossRef]

85. Habib, M.S.; Sarkar, B. A multi-objective approach to sustainable disaster waste management. Proc. Int. Conf. Ind. Eng. Oper. Manag. 2018, 2018, 1072-1083.

86. Habib, M.S.; Lee, Y.H.; Memon, S. Mathematical Models and Information Systems in Humanitarian Supply Chain Management: A Systematic Literature Review. 2015. Available online: https:/ /www.dbpia.co.kr/Journal/articleDetail?nodeId=NODE06561326 (accessed on 24 February 2021).

87. van Barneveld, K.; Quinlan, M.; Kriesler, P.; Junor, A.; Baum, F.; Chowdhury, A.; Junankar, P.N.; Clibborn, S.; Flanagan, F.; Wright, C.F. The COVID-19 pandemic: Lessons on building more equal and sustainable societies. Econ. Labour Relat. Rev. 2020, 31, 133-157. [CrossRef]

88. Trautrims, A.; Schleper, M.C.; Cakir, M.S.; Gold, S. Survival at the expense of the weakest? Managing modern slavery risks in supply chains during COVID-19. J. Risk Res. 2020, 23, 1067-1072. [CrossRef]

89. Yazdani, M.; Gonzalez, E.D.; Chatterjee, P. A multi-criteria decision-making framework for agriculture supply chain risk management under a circular economy context. Manag. Decis. 2019. [CrossRef]

90. Cao, C.; Li, C.; Yang, Q.; Liu, Y.; Qu, T. A novel multi-objective programming model of relief distribution for sustainable disaster supply chain in large-scale natural disasters. J. Clean. Prod. 2018, 174, 1422-1435. [CrossRef]

91. Ibrahim, S.E.; El Ebrashi, R. How social entrepreneurship can be useful in long-term recovery following disasters. J. Humanit. Logist. Supply Chain Manag. 2017. [CrossRef]

92. Yadav, D.K.; Barve, A. Modeling post-disaster challenges of humanitarian supply chains: A TISM approach. Glob. J. Flex. Syst. Manag. 2016, 17, 321-340. [CrossRef]

93. Zhang, F.; Wu, X.; Tang, C.S.; Feng, T.; Dai, Y. Evolution of Operations Management Research: From Managing Flows to Building Capabilities. Prod. Oper. Manag. 2020, 29, 2219-2229. [CrossRef]

94. Quayson, M.; Bai, C.; Osei, V. Digital Inclusion for Resilient Post-COVID-19 Supply Chains: Smallholder Farmer Perspectives. IEEE Eng. Manag. Rev. 2020, 48, 104-110. [CrossRef]

95. Mishra, S.; Singh, S.P. A stochastic disaster-resilient and sustainable reverse logistics model in big data environment. Ann. Oper. Res. 2020, 1-32. [CrossRef]

96. Kaur, H. Modelling internet of things driven sustainable food security system. Benchmarking Int. J. 2019. [CrossRef]

97. Papadopoulos, T.; Gunasekaran, A.; Dubey, R.; Altay, N.; Childe, S.J.; Fosso-Wamba, S. The role of Big Data in explaining disaster resilience in supply chains for sustainability. J. Clean. Prod. 2017, 142, 1108-1118. [CrossRef]

98. Boostani, A.; Jolai, F.; Bozorgi-Amiri, A. Designing a sustainable humanitarian relief logistics model in pre- and postdisaster management. Int. J. Sustain. Transp. 2020, 1-17. [CrossRef]

99. Zarei, M.H.; Carrasco-Gallego, R.; Ronchi, S. To Greener Pastures: An Action Research Study on the Environmental Sustainability of Humanitarian Supply Chains. Int. J. Oper. Prod. Manag. 2019, 39, 1193-1225. [CrossRef]

100. Laguna-Salvadó, L.; Lauras, M.; Okongwu, U.; Comes, T. A multicriteria Master Planning DSS for a sustainable humanitarian supply chain. Ann. Oper. Res. 2019, 283, 1303-1343. [CrossRef]

101. Andalib Ardakani, D.; Soltanmohammadi, A. Investigating and analysing the factors affecting the development of sustainable supply chain model in the industrial sectors. Corp. Soc. Responsib. Environ. Manag. 2019, 26, 199-212. [CrossRef] 
102. Silva, M.E.; Pereira, S.C.; Gold, S. The response of the Brazilian cashew nut supply chain to natural disasters: A practice-based view. J. Clean. Prod. 2018, 204, 660-671. [CrossRef]

103. Eskandari-Khanghahi, M.; Tavakkoli-Moghaddam, R.; Taleizadeh, A.A.; Amin, S.H. Designing and optimizing a sustainable supply chain network for a blood platelet bank under uncertainty. Eng. Appl. Artif. Intell. 2018, 71, 236-250. [CrossRef]

104. Peretti, U.; Tatham, P.; Wu, Y.; Sgarbossa, F. Reverse logistics in humanitarian operations: Challenges and opportunities. J. Humanit. Logist. Supply Chain Manag. 2015, 5, 253-274. [CrossRef]

105. Rabenasolo, B.; Zeng, X. A Risk-Based Multi-criteria Decision Support System for Sustainable Development in the Textile Supply Chain. In Handbook on Decision Making: Vol 2: Risk Management in Decision Making; Lu, J., Jain, L.C., Zhang, G., Eds.; Intelligent Systems Reference Library; Springer: Berlin/Heidelberg, Germany, 2012; pp. 151-170; ISBN 978-3-642-25755-1.

106. Ivanov, D. Revealing interfaces of supply chain resilience and sustainability: A simulation study. Int. J. Prod. Res. 2018, 56, 3507-3523. [CrossRef]

107. Ivanov, D.; Das, A.; Choi, T.-M. New Flexibility Drivers for Manufacturing, Supply Chain and Service Operations; Taylor \& Francis: Abingdon, UK, 2018.

108. Kayikci, Y. Stream processing data decision model for higher environmental performance and resilience in sustainable logistics infrastructure. J. Enterp. Inf. Manag. 2020, 34, 140-167. [CrossRef]

109. Kaur, H.; Singh, S.P. Sustainable procurement and logistics for disaster resilient supply chain. Ann. Oper. Res. 2019, 283, 309-354. [CrossRef]

110. Das, K. Integrating Lean, Green, and Resilience Criteria in a Sustainable Food Supply Chain Planning Model. Int. J. Math. Eng. Manag. Sci. 2019, 4, 259-275. [CrossRef]

111. Kunz, N.; Gold, S. Sustainable humanitarian supply chain management-Exploring new theory. Int. J. Logist. Res. Appl. 2017, 20, 85-104. [CrossRef]

112. Connelly, E.B.; Lambert, J.H.; Thekdi, S.A. Robust investments in humanitarian logistics and supply chains for disaster resilience and sustainable communities. Nat. Hazards Rev. 2016, 17, 04015017. [CrossRef]

113. Vargas, J.; González, D. Model to assess supply chain resilience. Int. J. Saf. Secur. Eng. 2016, 6, 282-292. [CrossRef]

114. Forbes Which Companies Did Well During The Coronavirus Pandemic? Available online: https://www.forbes.com/sites/ rohitarora/2020/06/30/which-companies-did-well-during-the-coronavirus-pandemic/ (accessed on 9 February 2021).

115. Forbes How COVID-19 Is Transforming E-Commerce? Available online: https://www.forbes.com/sites/louiscolum-bus/2020/0 4/28/how-covid-19-is-transforming-e-commerce/ (accessed on 9 February 2021).

116. Beltagui, A.; Kunz, N.; Gold, S. The role of 3D printing and open design on adoption of socially sustainable supply chain innovation. Int. J. Prod. Econ. 2020, 221, 107462. [CrossRef]

117. Wahl, B.; Cossy-Gantner, A.; Germann, S.; Schwalbe, N.R. Artificial intelligence (AI) and global health: How can AI contribute to health in resource-poor settings? BMJ Glob. Health 2018, 3, e000798. [CrossRef]

118. Javaid, M.; Haleem, A.; Vaishya, R.; Bahl, S.; Suman, R.; Vaish, A. Industry 4.0 technologies and their applications in fighting COVID-19 pandemic. Diabetes Metab. Syndr. Clin. Res. Rev. 2020, 14, 419-422. [CrossRef]

119. Mughal, M.P.; Farooq, M.U.; Mumtaz, J.; Mia, M.; Shareef, M.; Javed, M.; Jamil, M.; Pruncu, C.I. Surface Modification for Osseointegration of Ti6Al4V ELI Using Powder Mixed Sinking EDM. J. Mech. Behav. Biomed. Mater. 2021, 113, 104145. [CrossRef] [PubMed]

120. Umar Farooq, M.; Pervez Mughal, M.; Ahmed, N.; Ahmad Mufti, N.; Al-Ahmari, M.A.; He, Y. On the Investigation of Surface Integrity of Ti6Al4V ELI Using Si-Mixed Electric Discharge Machining. Mater. 2020, 13, 1549. [CrossRef] [PubMed]

121. Farooq, M.U.; Ali, M.A.; He, Y.; Khan, A.M.; Pruncu, C.I.; Kashif, M.; Ahmed, N.; Asif, N. Curved Profiles Machining of Ti6Al4V Alloy through WEDM: Investigations on Geometrical Errors. J. Mater. Res. Technol. 2020, 9, 16186-16201. [CrossRef]

122. Shepard, W. COVID-19 Undermines China's Run as the World's Factory, but Beijing has a Plan. Available online: https: / / www.forbes.com/sites/wadeshepard/2020/03/26/covid-19-undermines-chinas-run-as-the-worlds-factory-butbeijing-has-a-plan/ (accessed on 28 July 2020).

123. Settanni, E. Those who do not move, do not notice their (supply) chains-Inconvenient lessons from disruptions related to COVID-19. Ai Soc. 2020, 35, 1065-1071. [CrossRef]

124. Liu, Y.; Lee, J.M.; Lee, C. The challenges and opportunities of a global health crisis: The management and business implications of COVID-19 from an Asian perspective. Asian Bus. Manag. 2020, 19, 277-297. [CrossRef]

125. Dubey, R.; Gunasekaran, A.; Bryde, D.J.; Dwivedi, Y.K.; Papadopoulos, T. Blockchain technology for enhancing swift-trust, collaboration and resilience within a humanitarian supply chain setting. Int. J. Prod. Res. 2020, 58, 3381-3398. [CrossRef]

126. Bag, S.; Wood, L.C.; Mangla, S.K.; Luthra, S. Procurement 4.0 and its implications on business process performance in a circular economy. Resour. Conserv. Recycl. 2020, 152, 104502. [CrossRef]

127. Malik, A.A.; Masood, T.; Kousar, R. Repurposing factories with robotics in the face of COVID-19. Sci. Robot. 2020, 5, eabc2782. [CrossRef]

128. Attaran, M. 3D Printing Role in Filling the Critical Gap in the Medical Supply Chain during COVID-19 Pandemic. Am. J. Ind. Bus. Manag. 2020, 10, 988. [CrossRef]

129. Paul, S.K.; Sarker, R.; Essam, D.; Lee, P.T.-W. A mathematical modelling approach for managing sudden disturbances in a three-tier manufacturing supply chain. Ann. Oper. Res. 2019, 280, 299-335. [CrossRef] 
130. Currie, C.S.; Fowler, J.W.; Kotiadis, K.; Monks, T.; Onggo, B.S.; Robertson, D.A.; Tako, A.A. How simulation modelling can help reduce the impact of COVID-19. J. Simul. 2020, 14, 83-97. [CrossRef]

131. Pavlov, A.; Ivanov, D.; Werner, F.; Dolgui, A.; Sokolov, B. Integrated detection of disruption scenarios, the ripple effect dispersal and recovery paths in supply chains. Ann. Oper. Res. 2019, 1-23. [CrossRef]

132. Besiou, M.; Van Wassenhove, L.N. Humanitarian operations: A world of opportunity for relevant and impactful research. Manuf. Serv. Oper. Manag. 2020, 22, 135-145. [CrossRef]

133. Dubey, R.; Altay, N.; Blome, C. Swift trust and commitment: The missing links for humanitarian supply chain coordination? Ann. Oper. Res. 2019, 283, 159-177. [CrossRef]

134. Hosseini, S.; Ivanov, D.; Dolgui, A. Review of quantitative methods for supply chain resilience analysis. Transp. Res. Part E Logist. Transp. Rev. 2019, 125, 285-307. [CrossRef]

135. Hosseini, S.; Ivanov, D. Resilience assessment of supply networks with disruption propagation considerations: A Bayesian network approach. Ann. Oper. Res. 2019. [CrossRef]

136. Choi, T.-M. Innovative "Bring-Service-Near-Your-Home" Operations under Corona-Virus (COVID-19/SARS-CoV-2) Outbreak: Can Logistics Become the Messiah? Transp. Res. Part E Logist. Transp. Rev. 2020, 140, 101961. [CrossRef] [PubMed]

137. Dolgui, A.; Ivanov, D.; Rozhkov, M. Does the ripple effect influence the bullwhip effect? An integrated analysis of structural and operational dynamics in the supply chain. Int. J. Prod. Res. 2020, 58, 1285-1301. [CrossRef]

138. Dolgui, A.; Ivanov, D.; Potryasaev, S.; Sokolov, B.; Ivanova, M.; Werner, F. Blockchain-oriented dynamic modelling of smart contract design and execution in the supply chain. Int. J. Prod. Res. 2020, 58, 2184-2199. [CrossRef]

139. Reuters. Boeing to Cut $787 / 777$ Production as COVID-19 Hammers Sales. Available online: https://www.reuters.com/article/ boeing-results / boeing-to-cut-787-777-production-as-covid-19-hammers-sales-idUKL3N2F03B3 (accessed on 30 July 2020).

140. Reuters. COVID-19 Crushes U.S. Economy in Second Quarter; Rising Virus Cases Loom over Recovery. Available online: https: / / www.reuters.com/article/us-usa-economy-idUSKCN24V0FO (accessed on 30 July 2020).

141. Reuters. U.S. Second-Quarter GDP Falls at Steepest Rate since Great Depression. Available online: https://www.reuters.com/ article/us-usa-economy-instant-idUSKCN24V2GJ (accessed on 30 July 2020).

142. Malik, A.A.; Masood, T.; Kousar, R. Reconfiguring and ramping-up ventilator production in the face of COVID-19: Can robots help? J. Manuf. Syst. 2020, in press. [CrossRef]

143. Malik, A.A.; Masood, T.; Bilberg, A. Virtual reality in manufacturing: Immersive and collaborative artificial- reality in design of human-robot workspace. Int. J. Comput. Integr. Manuf. 2020, 33, 22-37. [CrossRef]

144. Elluru, S.; Gupta, H.; Kaur, H.; Singh, S.P. Proactive and reactive models for disaster resilient supply chain. Ann. Oper. Res. 2019, 283, 199-224. [CrossRef]

145. Masood, T.; Kern, M.; Clarkson, P.J. Characteristics of changeable systems across value chains. Int. J. Prod. Res. 2020. [CrossRef]

146. Egger, J.; Masood, T. Augmented reality in support of intelligent manufacturing-A systematic literature review. Comput. Ind. Eng. 2020, 140, 106195. [CrossRef]

147. Masood, T.; Sonntag, P. Industry 4.0: Adoption challenges and benefits for SMEs. Comput. Ind. 2020, 121, 103261. [CrossRef]

148. Masood, T.; Egger, J. Adopting augmented Reality in the age of Industrial Digitalisation. Comput. Ind. 2020, 115, 103112. [CrossRef]

149. Masood, T.; Egger, J. Augmented reality in support of Industry 4.0-Implementation challenges and success factors. Robot. Comput. Integr. Manuf. 2019, 58, 181-195. [CrossRef]

150. Aven, T. How some types of risk assessments can support resilience analysis and management. Reliab. Eng. Syst. Saf. 2017, 167, 536-543. [CrossRef]

151. Dolgui, A.; Proth, J.-M. Supply Chain Engineering: Useful Methods and Techniques; Springer Science \& Business Media: Berlin, Germany, 2010.

152. Masood, T.; Egger, J.; Kern, M. Future-proofing the through-life engineering service systems. Procedia Manuf. 2018, 16, 179-186. [CrossRef] 